\title{
PREDIÇÃO LEITORA E CONSCIÊNCIA TEXTUAL: UM ESTUDO COM ALUNOS DO ENSINO FUNDAMENTAL
}

\author{
Danielle Baretta ${ }^{1 \times}$ \\ Vera Wannmacher Pereira ${ }^{1 * *}$ \\ ${ }^{1}$ Pontifícia Universidade Católica do Rio Grande do Sul, Porto Alegre, RS, Brasil
}

\begin{abstract}
Resumo
Apoiado em estudos psicolinguísticos, este artigo trata da compreensão leitora com foco no uso da predição e no nível de consciência textual no uso dessa estratégia. Para tanto, realizou-se uma pesquisa com 55 alunos, entre 11 e 13 anos, que cursavam o $6^{\circ}$ ano do Ensino Fundamental de uma escola pública da cidade de Porto Alegre. Para examinar o uso da predição, aplicouse uma tarefa de leitura, na qual uma fábula foi apresentada em fichas que continham uma parte da história e perguntas que estimulavam o uso dessa estratégia. Para verificar o nível de consciência textual dos participantes, utilizou-se o protocolo verbal de autorrevelação. Os resultados mostraram que a maioria dos alunos manejou bem o uso da predição leitora, fazendo antecipações pertinentes, embora $27 \%$ deles ainda não tenham tido sucesso nesse empreendimento. Com relação à consciência textual no uso dessa estratégia, pouco mais da metade dos alunos evidenciaram comportamento metalinguístico, tendo sido capaz de explicar com eficiência as bases geradoras de suas predições com informações intratextuais ou extratextuais, enquanto $47 \%$ não alcançou esse êxito, uma vez que respondiam de forma confusa e equivocada ou, quando apresentavam indícios de como processaram a questão, o faziam com informações vagas ou imprecisas. Considerando-se o contexto escolar, os resultados da pesquisa sugerem que tanto o uso da predição leitora quanto a consciência sobre esse uso são tópicos de trabalho inadiáveis nas aulas de Língua Portuguesa, pois oferecem ao professor informações sobre o processo de leitura dos alunos, em suas possibilidades e dificuldades.

Palavras-chave: Compreensão Leitora; Processamento da Leitura; Predição Leitora; Consciência Textual.
\end{abstract}

\footnotetext{
“É licenciada em Letras Português / Espanhol. Mestre em Linguística, possui especialização em Estudos Avançados em Língua Espanhola e em Língua Portuguesa com ênfase em Multiletramentos. Desenvolve seus estudos de Doutorado na área de Psicolinguística, na Pontifícia Universidade Católica do Rio Grande do Sul sob a orientação da Profa. Dra. Vera Wannmacher Pereira. É professora de Língua Portuguesa do Colégio Militar de Porto Alegre. Seu e-mail é: daniellebaretta@hotmail.com. ORCID: https://orcid.org/0000-0003-2679-767.

${ }^{*}$ É licenciada em Letras. Desenvolveu seu mestrado e seu Doutorado em Letras / Linguística Aplicada. Realizou seu Pós-doutorado em Psicolinguística. É bolsista PD/DT CNPq. Atualmente é professora titular e permanente do Programa de Pós-graduação em Letras da Pontifícia Universidade Católica do Rio Grande do Sul. É coordenadora do Núcleo de Pesquisa em Cognição, Cultura, Linguagens e Interfaces: ciência, arte e tecnologia da Escola de Humanidades - Letras/PUCRS. Desenvolve pesquisas na área da Compreensão e do Processamento da Leitura e da Escrita. Seu e-mail é: vpereira@pucrs.br. ORCID ID https://orcid.org/00000002-2511-6814.
} 


\title{
READING PREDICTION AND TEXTUAL AWARENESS: A STUDY WITH PRIMARY EDUCATION STUDENTS
}

\begin{abstract}
Based on psycholinguistic studies, this article deals with reading comprehension skills focusing prediction and the textual consciousness level imbricated in this strategy. To demonstrate this theory, a research has been carried on with 55 sixth grade-students whose ages ranged from 11 to 13, all attending the elementary educational level of a public school in the city of Porto Alegre. In order to examine the effective use of predictions, a reading task with parts of a fable was presented in paper cards, as well as questions about the story to stimulate the use of those strategies. The verbal protocol of self-revelation was adopted to verify the participants' textual level of consciousness. The results showed that most of the students managed to deal with reading prediction, making pertinent anticipations, although $27 \%$ of them were unsuccessful. In relation to the textual consciousness in the use of this strategy, just over half of the students showed metalinguistic behavior, being capable to explain the generative bases of their predictions efficiently using both intratextual and extratextual information. Nevertheless, $47 \%$ of the pupils were not able to achieve the goal, since they responded the questions in a confusing and mistaken manner or used vague and imprecise information while showing evidences of how they had processed the question. Considering the educational context, the research results suggested that both the use of the reading prediction and its conscious awareness are relevant topics to be applied in Portuguese language classes, for they provide the teacher with information concerning the possibilities and difficulties on students' reading process.

Keywords: Reading Comprehension; Reading Processing; Reading Prediction; Textual Awareness.
\end{abstract}




\section{Introdução}

Provas oficiais que analisam o desempenho em leitura dos estudantes constatam que os índices alcançados pelos alunos brasileiros são insatisfatórios. Segundo relatório da Organização para Cooperação e Desenvolvimento Econômico (OCDE) de 2016, o desempenho em leitura dos estudantes brasileiros, em 2015, piorou em relação a 2012. De acordo com dados do Programa Internacional de Avaliação de Alunos (PISA), o país somou 407 pontos em leitura, três a menos do que sua pontuação na avaliação anterior, sendo que a média dos países avaliados foi de 493 pontos. Com isso, o Brasil ficou na 59a posição no ranking de leitura.

O relatório destaca, ainda, que mais da metade (50,99\%) dos alunos brasileiros não alcançou o nível 2 de desempenho na avaliação que tem o nível 7 como teto. Isso significa que eles não foram capazes de reconhecer a ideia principal de um texto, realizar inferências elementares, entender relações, compreender significados dentro de uma parte delimitada do texto e estabelecer comparações ou conexões entre o texto e conhecimentos externos.

Esses resultados indicam a preocupante condição de compreensão leitora dos estudantes do Ensino Fundamental e Médio e revelam a situação em que se encontra o ensino de leitura nas escolas brasileiras, ainda dominado por práticas pedagógicas pouco produtivas.

Nas aulas de Língua Portuguesa, as atividades de leitura focalizam, na maioria das vezes, questões referentes ao conteúdo, com o objetivo de realizar associações com o mundo do aluno. O trabalho com os elementos linguísticos do texto é feito após as atividades de compreensão e delas desvinculado, caracterizando-se, via de regra, pelo ensino de normas gramaticais classificatórias. Com relação ao uso de estratégias de leitura, há uma prevalência por estratégias como o skimming, em que o leitor passa os olhos pelo texto, buscando identificar sua ideia geral, e o scanning, que consiste na localização de informações específicas no texto. Estratégias que exigem operações cognitivas mais complexas como inferência, predição, automonitoramento, entre outras, são pouco trabalhadas, como demonstra um estudo realizado por Marcuschi (2008), que analisou exercícios de compreensão leitora de diversos livros didáticos adotados no Ensino Fundamental em escolas da cidade de Recife. Os resultados mostraram que a maior parte das atividades exigia do aluno a cópia de trechos literais do texto e que somente $5 \%$ das perguntas requeriam o estabelecimento de relações e inferências.

Diante desse quadro, evidencia-se a necessidade de se examinarem as práticas de leitura na escola, revendo as estratégias adotadas. Nesse sentido, nas últimas décadas, tem crescido o número de pesquisas que estudam a forma como os alunos processam a leitura, buscando compreender os caminhos cognitivos percorridos pelo leitor na construção do sentido do texto. Esses estudos têm destacado a importância das estratégias de leitura, uma vez que é por meio delas que o leitor interage com o texto na busca da compreensão. Dentre os diferentes tipos nomeados pela literatura, a predição leitora, isto é, a antecipação 
de conteúdos do texto, tem se destacado como componente importante no processamento cognitivo da leitura (GOODMAN, 1976; SMITH, 2003; GIASSON, 2001; SPINILLO e ALMEIDA, 2014; SPINILLO e MAHON, 2015; CASTRO e PEREIRA, 2004; PEREIRA, 2002, 2003, 2009, 2011, 2012; PEREIRA e SANTOS, 2017). Além do reconhecimento da relevância das estratégias de leitura, pesquisas recentes (SPINILLO, MOTA e CORREA, 2010; LORANDI et al, 2012; ANÇÃ, 2015; PEREIRA e SANTOS, 2017) sugerem que a eficácia do processo de leitura está relacionada à habilidade do indivíduo de refletir sobre os próprios conhecimentos linguísticos, isto é, à sua consciência linguística.

Nesse sentido, o objetivo do estudo aqui apresentado foi examinar a compreensão leitora de estudantes do $6^{\circ}$ ano do Ensino Fundamental no que se refere à realização de predições sobre o conteúdo de uma fábula e o nível de consciência textual no uso dessa estratégia, com apoio nos elementos intratextuais e extratextuais. Para tanto, são apresentados, a seguir, os fundamentos teóricos que dão suporte ao estudo, a descrição da pesquisa realizada e os resultados obtidos. Nas conclusões, são apresentadas relações entre a pesquisa desenvolvida e a prática pedagógica, indicando caminhos possíveis para o ensino da leitura.

\section{Fundamentação teórica}

A fundamentação teórica que embasa o presente estudo parte de pressupostos psicolinguísticos referentes à prática da leitura. Desse modo, são apresentados a seguir aspectos concernentes ao processamento cognitivo da leitura, ao uso de estratégias de leitura, em especial a predição leitora, bem como ao papel da consciência linguística nesse uso com foco na consciência textual.

\section{1 Leitura numa perspectiva psicolinguística}

$\mathrm{Na}$ concepção psicolinguística, a leitura é considerada uma prática de construção de sentidos e seu produto primário é a compreensão. Nesse sentido, o universo cognitivo do leitor é fundamental, uma vez que a leitura é, segundo Koch e Elias (2011), uma atividade interativa altamente complexa de produção de sentidos, que se realiza com base na relação entre o conhecimento que o leitor traz armazenado na memória e as informações veiculadas no texto. Para as autoras, não se pode falar do sentido do texto e sim de um sentido para o texto, que somente será construído na interação com o leitor (KOCH e ELIAS, 2011).

Nesse processo, o leitor, a partir das informações disponíveis no texto, seleciona aquelas que considera mais relevantes tendo em vista seus objetivos de leitura. Essas informações ativam, em sua memória, o conhecimento prévio que possui sobre o assunto, permitindo-lhe integrar o dado novo ao já existente e, assim, construir o sentido do texto.

A leitura, portanto, não é um processo passivo no qual o leitor extrai sentidos do texto a partir do reconhecimento das intenções do autor ou do reconhecimento das palavras e estruturas do texto. Na realidade é a interação 
entre todos esses elementos que resultará na compreensão do sentido do texto. Desse modo, o conhecimento prévio do leitor não é suficiente para que ele compreenda o que lê. É fundamental que o leitor reconstrua o percurso trilhado pelo autor, reconhecendo as pistas linguísticas por ele deixadas no texto. É por isso que Kato (2007, p. 72) afirma que o texto é "um conjunto de pegadas a serem utilizadas para recapitular as estratégias do autor e através delas chegar aos seus objetivos". Isso significa que, embora não se possa falar em um sentido único do texto, também não se pode considerar que toda interpretação é possível, pois para que a compreensão seja efetiva é necessário que as hipóteses e inferências realizadas pelo leitor encontrem amparo na materialidade do texto. Os elementos linguísticos do texto que, em outras concepções de leitura, são supervalorizados ou depreciados, são aqui considerados parte de uma relação triangular entre autortexto-leitor, na qual o leitor usa os dados fornecidos pelo autor, selecionando as informações relevantes para chegar a um sentido autorizado pelo texto.

Marcuschi (2008) ilustra esse aspecto valendo-se da metáfora criada por Dascal, que imagina o texto como uma cebola. Segundo o autor, as camadas internas representam as informações objetivas, elementos tipicamente informacionais do texto e que não são passíveis de interpretações diversas, como nomes, lugares etc. A camada intermediária, por sua vez, é o terreno das inferências, isto é, das diferentes, porém válidas leituras. A camada mais externa é a mais sujeita a equívocos, pois consiste no domínio de nossas crenças e valores. É nesse domínio que surgem as extrapolações, os sentidos não autorizados pelo texto.

Esse processo de construção do sentido durante a leitura ocorre, segundo Poersch (1991), em níveis que são estabelecidos por critérios de abrangência textual e de profundidade de compreensão. $O$ critério de abrangência está relacionado, de acordo com o autor, com a tríplice articulação linguística: lexical, frasal e textual. A compreensão lexical refere-se ao reconhecimento do significado das palavras; já a compreensão frasal consiste em reconhecer o sentido que as palavras assumem na frase, pois, como afirma Poersch (1991, p. 130), "o significado de uma frase não corresponde ao somatório do significado das palavras". A compreensão textual, por sua vez, envolve o reconhecimento do sentido global do texto.

O segundo critério, o de profundidade, corresponde à compreensão do sentido explícito, isto é, daquilo que está efetivamente escrito no texto, e do sentido implícito, ou seja, o que não está escrito, mas faz parte do texto; e do sentido metaplícito, proveniente de dados externos ao texto, relativos à situação de comunicação.

A construção desses sentidos é realizada por meio de processos que exigem diferentes demandas cognitivas. O primeiro, o conteúdo explícito, deriva de uma atividade de decodificação. $O$ conteúdo implícito exige processos mentais mais complexos, como a inferência e a pressuposição. O metaplícito, por sua vez, é construído a partir do conhecimento prévio de cada indivíduo.

Diante disso, fica claro que a leitura deve ser entendida como um processo e não como um produto, pois o texto "não traz tudo pronto para o leitor receber 
de modo passivo" (KLEIMAN, 2013, p. 36). Esse processo ocorre de diferentes maneiras, como se pode ver na próxima seção.

\subsubsection{Processamento da leitura}

Diferentes autores (LEFFA, 1996; SOLÉ, 1998; KATO, 2007; SCLIAR-CABRAL, 2008) apontam dois tipos básicos de processamento da leitura: o processamento ascendente (bottom-up) e o processamento descendente (top-down).

O processamento bottom-up enfatiza o texto e as informações nele presentes como ponto de partida para a compreensão. Nesse tipo de processamento, o leitor parte das unidades menores para as maiores. Todas as pistas visuais são utilizadas para, a partir do reconhecimento de palavras, frases, orações compor um todo até chegar à compreensão. Segundo Solé (1998), as propostas de ensino baseadas nesse modelo centram sua atenção no desenvolvimento de habilidades de decodificação, pois consideram que o leitor pode compreender o texto na medida em que pode decifrá-lo totalmente.

No processamento top-down, por sua vez, o leitor parte do seu conhecimento prévio, seja ele linguístico ou extralinguístico, para atribuir sentido ao texto, realizando antecipações sobre a leitura. Ao contrário da abordagem bottom-up, o modelo top-down coloca o leitor no centro do processo de leitura, uma vez que o sentido é construído a partir do conhecimento que o leitor traz consolidado na memória. Para Goodman (1976, p. 12), um dos precursores dessa abordagem, a leitura é "um processo psicolinguístico que começa com uma representação linguística codificada pelo escritor e termina com o significado construído pelo leitor".

Castro e Pereira (2004) alertam que, no processamento da leitura, o leitor não pode apenas considerar seu conhecimento prévio sem basear-se nos elementos linguísticos do texto (processo descendente), pois correria o risco de construir um sentido equivocado, que não encontra suporte no texto. Igualmente, não pode considerar somente os elementos linguísticos, sem relacioná-los com o que já conhece sobre o conteúdo (processo ascendente), pois, para relacionar as informações em nível local (palavras, frases e sentenças) e global (texto como um todo), elas precisam estar integradas ao conhecimento prévio do leitor.

Esses dois tipos de processamentos, portanto, não são excludentes, mas complementares, uma vez que, como afirma Leffa (1996), a leitura implica correspondência entre o conhecimento prévio do leitor e os dados do texto, gerando novos conhecimentos. Dessa concepção, provém um terceiro tipo de processamento: o interativo, que combina características dos outros dois modelos.

No processamento interativo, o foco não está nem no leitor, nem no texto, mas na interação entre os conhecimentos já construídos pelo leitor e os dados apresentados pelo texto. Nesse processo, o leitor faz perguntas a partir de seu conhecimento linguístico, textual e de mundo. Para respondê-las, deverá buscar no texto as pistas que sustentarão ou não suas hipóteses. A compreensão ocorre quando essas perguntas são respondidas (SMITH, 2003). 
Um dos modelos interativos de maior aceitação na literatura - o Modelo de Construção-Integração de Kintsch (1998) - considera a compreensão um processo inferencial por natureza. Esse modelo consiste em duas dimensões que se relacionam entre si: o texto base, uma representação mental construída a partir de informações explicitadas no texto; e o modelo situacional, uma representação mental realizada a partir do conhecimento prévio do leitor na qual as lacunas do texto são preenchidas por meio do estabelecimento de inferências. O modelo é considerado interativo, pois prevê que, durante a leitura, o leitor integre os elementos do texto-base para, desse modo, construir a representação mental do texto, relacionando informações no nível intratextual e extratextual.

A concepção de leitura assumida nesta pesquisa ampara-se no modelo interativo, pois entende, assim como Kato (2007), que o leitor maduro é aquele capaz de usar ambos os processos de modo complementar, dependendo do tipo de texto que está lendo, de sua motivação, de seus objetivos de leitura e das dificuldades que enfrenta durante a leitura, fatores envolvidos no processamento da leitura. O próximo tópico trata da influência desses fatores no processo de compreensão de um texto.

\subsubsection{Fatores envolvidos no processamento da leitura}

O processo da leitura envolve diferentes aspectos que se referem tanto às características do texto quanto às características do leitor. Ao longo da história, diferentes estudos têm abordado um ou outro aspecto.

Com relação ao texto, o gênero textual, os fatores linguísticos, como o léxico, a estrutura sintática, e até mesmo os aspectos materiais, como o tamanho e a clareza das letras, são elementos que podem interferir no processo de leitura, de modo a dificultá-lo ou facilitá-lo (COLOMER e CAMPS, 2002). Com relação ao leitor, aspectos relacionados a diferenças individuais, tais como motivação, conhecimento do conteúdo, capacidade da memória de trabalho, entre outros, podem afetar o processamento do texto (SOUZA e HÜBNER, 2015).

Segundo Leffa (1996, p. 143-144), a melhoria da compreensão, no primeiro caso, está atrelada à melhoria das qualidades intrínsecas do texto. No segundo, por sua vez, considera-se que a compreensão aumenta à medida que se desenvolvem as habilidades gerais do leitor. Para o autor, uma descrição completa do processo da compreensão, no entanto, deve levar em conta não só o texto e o leitor, mas as circunstâncias em que se dá esse encontro.

Nesse sentido, Spinillo (2013) comenta que a reflexão sobre a compreensão de textos deve considerar três instâncias: o leitor, o texto e a interação entre eles. A compreensão, para a autora, deriva da relação entre o leitor que, durante a leitura, aciona um conjunto de habilidades cognitivas, e o texto, escrito sob certa forma linguística e com um propósito comunicativo específico, inseridos em uma determinada situação. Essas instâncias caracterizam, segundo a pesquisadora, as três dimensões que envolvem a compreensão: a dimensão social, a linguística e a cognitiva. A primeira diz respeito ao conhecimento sociocultural, às expectativas e objetivos de leitura em determinado contexto 
social. A segunda, por sua vez, refere-se à materialidade linguística do texto que se constitui no nível da palavra, da sentença e do texto como um todo. A última supõe aspectos relativos ao processamento das informações, tais como a memória, o monitoramento e as inferências.

A compreensão é, portanto, uma atividade complexa na qual intervêm diferentes fatores inter-relacionados e indissociáveis. Colomer e Camps (2002, p. 47) comentam que conhecer os aspectos que influem no grau de compreensão da leitura é de grande interesse para o planejamento educativo dessas aprendizagens, já que a capacidade de entender um texto e a possibilidade de ensinar a fazê-lo são consideradas pontos chave da leitura e de seu ensino. Alguns desses aspectos serão detalhados a seguir.

\subsubsection{Objetivos da leitura}

Como mencionado anteriormente, o sentido não está no texto, mas é construído pelo leitor em um processo de interação entre o que está escrito e o conhecimento que ele já possui. É por isso que leitores diferentes podem construir sentidos diferentes a partir da leitura de um mesmo texto. Os objetivos de leitura determinam a forma como o leitor interagirá com o texto e a relevância que atribuirá às informações do texto. Esses objetivos podem ser muitos e variam conforme a situação e o interesse do leitor no momento da leitura, de modo que não só leitores diferentes podem construir sentidos diferentes para um mesmo texto, como também um mesmo leitor, dependendo de seu objetivo e motivação, pode compreender o mesmo texto de diferentes formas. É possível que um leitor que precise fazer um trabalho escolar, por exemplo, ao deparar-se com um texto sobre o assunto de sua pesquisa, faça uma leitura rápida, saltando partes, buscando obter uma ideia geral do texto, com o intuito de verificar se, de fato, o material poderá auxiliá-lo em seu estudo. Uma vez selecionado o texto, em um momento posterior, esse mesmo leitor fará uma leitura mais detalhada, que exigirá um nível de compreensão mais profundo, tendo em vista que o objetivo agora é obter informações para redigir um texto.

É preciso considerar também, como destacam Colomer e Camps (2002), que as características do texto já pressupõem uma forma determinada de leitura. A leitura de um anuário, por exemplo, não poderia ser realizada da mesma forma que a de uma narrativa. No entanto, as autoras salientam que é, sobretudo, o propósito da leitura que determinará não só a forma como o leitor abordará o texto como também o nível de compreensão que tolerará ou exigirá para considerar boa sua leitura (COLOMER e CAMPS, 2002).

Foucambert (2008) afirma que ler é escolher algo e que, portanto, sem essa intenção, a leitura não existe. É em função disso que, para o autor, a leitura é, por natureza, flexível, multiforme e sempre adaptada ao que se busca. Kleiman (2013, p. 35) também compartilha desse ponto de vista, pois acredita que "a leitura que não surge de uma necessidade para chegar a um propósito não é propriamente leitura". Nesse caso, será uma atividade mecânica, muito mais baseada na decodificação do que na construção do sentido. 
Com relação ao contexto escolar, Kleiman (2013) menciona que, enquanto na prática cotidiana o aluno é perfeitamente capaz de estabelecer objetivos de leitura e planejar as ações para alcançá-los, na escola, na maioria das vezes, esse estudante começa a ler sem ter ideia de onde quer chegar e, portanto, sem saber como chegará lá, uma vez que as atividades de leitura se constituem, geralmente, em um pretexto para outras tarefas de ensino, como análises gramaticais, cópias ou resumos.

Solé (1998) também comenta a respeito da importância de objetivos definidos para o êxito em uma atividade de leitura. Para ela, é imprescindível estabelecer objetivos antes de iniciar a leitura, porque são eles que determinarão as estratégias mais adequadas à situação. São as estratégias de leitura que auxiliam o leitor a selecionar e avaliar as hipóteses que ele vai formulando sobre o conteúdo do texto durante a leitura, por isso, para utilizá-las eficientemente, é necessário saber qual é o objetivo que se quer alcançar. É em função disso que a autora destaca a importância de se trabalharem na escola atividades de leitura que apresentem diferentes propósitos e que, portanto, exijam o uso de diferentes estratégias de leitura. Embora considere que os objetivos dos leitores com relação a um texto podem ser muito variados, Solé menciona alguns objetivos gerais cuja presença é importante para a vida adulta e que podem ser trabalhados na escola. São eles: ler para obter uma informação precisa; ler para seguir instruções; ler para obter uma informação de caráter geral; ler para aprender; ler para revisar um escrito próprio; ler por prazer e ler para comunicar um texto para um auditório.

Kleiman (2013) comenta que uma diferença entre leitores experientes e leitores menos experientes é que estes têm dificuldade em determinar objetivos para sua leitura, enquanto aqueles são capazes de fazê-lo de forma apropriada. Desse modo, a predeterminação de objetivos por um leitor proficiente pode ser importante como modelo, pois permitirá que o leitor iniciante, com o tempo, adote esse modelo, desenvolvendo estratégias necessárias para a compreensão e seja capaz de utilizá-las de forma autônoma.

Para a autora, estabelecer um objetivo à leitura permite ampliar não só a capacidade de processamento como também de memória do leitor. Quando o leitor tem um objetivo para sua leitura, ele ficará disponível em sua memória de trabalho durante todo o processo de leitura, de modo a guiá-lo no reconhecimento das informações mais relevantes para o cumprimento de seu propósito.

Além dos objetivos, o conhecimento prévio do leitor tem sido considerado um fator decisivo na leitura, afetando a compreensão de qualquer tipo de texto (LEFFA, 1996). Dada sua comprovada importância, esse tópico é desenvolvido na próxima seção.

\subsubsection{Conhecimentos prévios}

Muitos autores, entre eles Kleiman (2013) e Leffa (1996), discutem o papel do conhecimento prévio no processamento da leitura. Para Kleiman (2013), a leitura é considerada um processo interativo justamente porque nela o leitor utiliza o que já sabe, isto é, os esquemas linguísticos e conceituais armazenados na memória, para construir o sentido do texto. 
Para Leffa (1996), a leitura implica uma correspondência entre o conhecimento prévio do leitor e os dados fornecidos pelo texto, de modo que "a visão da realidade provocada pela presença do texto depende da bagagem de experiências prévias que o leitor traz para sua leitura" (LEFFA, 1996, p. 14).

Também Smith (2003) considera que, embora importante, a informação visual não é suficiente para a compreensão. Segundo o autor, ao ler, o leitor precisa comparar as informações obtidas do texto com aquelas que já possui, portanto, quanto mais informação não visual, isto é, quanto mais conhecimento o leitor possuir armazenado na memória, melhor será a sua compreensão. É em função disso que o autor menciona que crianças em processo de aquisição da linguagem escrita apresentam, muitas vezes, dificuldades de compreensão, pois tendem a fixar-se na informação visual. Desse modo, informações óbvias para um leitor experiente, frequentemente não o são para o leitor iniciante, em virtude da falta de conhecimento ou experiências sobre determinado assunto.

Considerando que a leitura é entendida como um processo interativo, no qual o leitor elabora hipóteses, predições sobre o texto, observando seus aspectos gráficos para poder testá-las, "a qualidade do ato da leitura não é medida pela qualidade intrínseca do texto, mas pela qualidade da reação do leitor" (Leffa, 1996, p. 14). Essa reação refere-se, segundo Kleiman (2013, p. 27), “(...) a uma atividade de procura realizada pelo leitor, no seu passado de lembranças e conhecimentos, daqueles que são relevantes à compreensão de um texto, que fornece pistas e sugere caminhos, mas que certamente não explicita tudo o que seria possível explicitar". Nessa acepção, "leitor e texto são como duas engrenagens correndo uma dentro da outra; onde faltar encaixe nas engrenagens, leitor e texto se separam e ficam rodando soltos" (LEFFA, 1996, p. 22).

Nesse processo interativo entre texto e leitor, este utiliza, segundo Kleiman (2013), diferentes níveis de conhecimento que interagem entre si. A autora ressalta que esses conhecimentos, além de interativos, são compensatórios, pois,

quando há problemas no processamento em um nível, outros tipos de conhecimento podem ajudar a desfazer a ambiguidade ou obscuridade, num processo de engajamento da memória e do conhecimento do leitor (...), isto é, quando o leitor é incapaz de chegar à compreensão através de um nível de informação, ele ativa outros tipos de conhecimento para compensar as falhas momentâneas (Kleiman, 2013, p. 24)

Para Kleiman (2013), o conhecimento prévio é o conhecimento adquirido pelo leitor ao longo de sua vida e engloba o conhecimento de mundo, o conhecimento linguístico e o conhecimento textual.

O conhecimento de mundo, que engloba o conhecimento enciclopédico, abrange não só conhecimentos gerais sobre o mundo, como também conhecimentos referentes a vivências pessoais e eventos situados no tempo e no espaço (KOCH e ELIAS, 2011), podendo ser construído tanto formalmente quanto informalmente, através de experiências e convívio numa sociedade. É uma espécie de conhecimento cultural arquivado e organizado na memória 
em blocos, denominados modelos cognitivos globais (KLEIMAN, 2013). É esse conhecimento que faz com que o leitor relacione as informações do texto, informações não expressas explicitamente, realizando inferências e predições importantes para alcançar uma compreensão coerente e global (FULGÊNCIO e LIBERATO, 2004).

O conhecimento linguístico desempenha papel central no processamento do texto, pois, sem ele, a compreensão não é possível. Isso ocorre porque, segundo Koch e Elias (2006), é esse conhecimento que possibilita ao leitor compreender a organização do material linguístico na superfície textual; o uso de meios coesivos para realizar a remissão ou sequenciação textual e a seleção lexical adequada ao tema ou modelo cognitivo. O conhecimento linguístico abrange desde "o conhecimento sobre como pronunciar uma língua, passando pelo conhecimento de vocabulário e regras da língua, chegando até o conhecimento sobre o uso da língua" (KLEIMAN, 2013, p. 13).

O conhecimento textual, por sua vez, inclui todo o conjunto de noções e conceitos sobre o texto e que são fundamentais à compreensão textual. Cada gênero textual possui características específicas que o distinguem de outros gêneros e que são convencionais no meio em que são empregadas. Desse modo, "quanto mais conhecimento textual o leitor tiver, quanto maior a sua exposição a todo tipo de texto, mais fácil será sua compreensão, pois o conhecimento de estruturas textuais e de tipos de discurso determinará as expectativas do leitor em relação ao texto" (KLEIMAN, 2013, p. 20). Esse tipo de conhecimento é chamado de conhecimento da situação comunicativa por Colomer e Camps (2002). Para as autoras, o leitor deve aprender a contextualizar, percebendo, por meio de elementos linguísticos, o objetivo da comunicação, em que tempo e lugar se produz, contrastando com seus próprios objetivos de leitura.

Tendo em vista esses aspectos, Stanke (2007), partindo das palavras de Kleiman, sugere que a escola busque proporcionar ao aluno atividades que o possibilitem reconhecer seu papel ativo na leitura e construção do sentido, através do engajamento de seus conhecimentos linguísticos, textuais e, principalmente, de mundo, com base nas marcas formais do texto. Esse engajamento do leitor na construção do sentido se dá por meio das estratégias de leitura, detalhadas a seguir.

\subsection{Estratégias de leitura: definição e tipologia}

O termo "estratégia" pode ser definido como um "procedimento, com frequência chamado também de regra, técnica, método, destreza ou habilidade, um conjunto de ações ordenadas e finalizadas dirigidas à consecução de uma meta" (COLL, 1987, p. 89). As estratégias usadas na compreensão de um texto constituem um conjunto de operações mentais que o leitor realiza na interação com o texto para construir sentido (SOLÉ, 1998; KLEIMAN, 2013). Para Goodman (1999), uma estratégia é um amplo esquema para obter, avaliar e utilizar informação. Essas estratégias utilizadas na compreensão de um texto são, 
segundo o autor, ativadas durante o próprio processo de leitura, por isso elas não podem ser aprendidas, mas desenvolvidas.

Diferentes estudiosos têm classificado as estratégias de leitura em cognitivas e metacognitivas (LEFFA, 1996; SOLÉ, 1998; KATO, 2007; KLEIMAN, 2013). As primeiras são ações que o leitor realiza para atingir um objetivo de leitura sem estar consciente delas. As segundas, por sua vez, referem-se a atividades intencionais e reflexivas no processo de compreensão do texto, são ações que o leitor realiza de forma consciente, podendo explicá-las.

Estudos sobre as estratégias de leitura (PEREIRA, 2011; PEREIRA e VARGAS, 2017) apresentam e caracterizam diferentes tipos de estratégias ativadas no processo de leitura. Entre elas, podemos destacar as elencadas a seguir.

O skimming consiste na busca de uma visão global do texto. Ao empregála, o leitor passa os olhos pelo texto, buscando identificar sua ideia geral. É depois do skimming que ele decide se deve ou não prosseguir na leitura, aprofundando-a. O scanning, assim como o skimming, caracteriza-se pela ação de percorrer o texto com olhos. A diferença está no fato de que neste, o objetivo é fazer um levantamento geral do texto, enquanto que naquele o leitor busca por uma informação específica, que lhe é necessária. Já a estratégia de seleção consiste na escolha de alguns segmentos do texto (palavras, frases, parágrafos) que são destacados pelo leitor, tendo em vista determinado objetivo. A leitura detalhada, como o próprio nome já indica, caracteriza-se por uma leitura paciente, minuciosa, na qual o leitor focaliza cada elemento linguístico presente no texto. A inferência, por sua vez, é uma dedução realizada pelo leitor baseada em pistas linguísticas e em elementos contextuais. A predição, estratégia que encontra suporte na inferência, consiste na antecipação de conteúdos do texto com base em pistas linguísticas e no conhecimento prévio do leitor. Ao formular hipóteses, o leitor terá que testá-las para confirmar ou não suas predições. Para tanto, necessitará do automonitoramento, da autoavaliação e da autocorreção, estratégias geralmente associadas. Essas estratégias são empregadas quando o leitor monitora os procedimentos que utiliza, avaliando-os e corrigindo-os, caso detecte algum equívoco no processo.

\subsubsection{Dificuldades de compreensão: o uso (ou a falta de uso) de estratégias metacognitivas de leitura}

As estratégias metacognitivas de leitura, conforme afirma Solé (1998), desempenham um papel muito importante nos processos envolvidos na compreensão leitora, pois auxiliam o leitor a selecionar, avaliar, persistir, abandonar ou alterar hipóteses que ele vai criando sobre o conteúdo que está lendo. Nesse contexto, o leitor passa a ter controle do processo de leitura. Uma palavra desconhecida ou um momento de desatenção, por exemplo, podem ser superados pelo controle, avaliação e monitoramento da leitura (KLEIMAN, 2013).

Esse monitoramento do comportamento como leitor, segundo Pedrosa (1984), começa desde muito cedo. A autora comenta que a diferença entre crianças 
menos e mais experientes reside no nível linguístico em que tal monitoramento se dá. As menos experientes começam monitorando a nível da palavra, para progressivamente passarem a monitorar a nível de sintagmas, orações e unidades maiores que o período. No mesmo estudo, Pedrosa mostrou que muitas crianças deixam de preencher lacunas do texto, o que demonstraria que elas têm consciência da existência de uma falha em sua compreensão. Essa concepção também é compartilhada por Brown (1980) ao afirmar que o bom estudante pode ser aquele que, com frequência, diz que não entendeu simplesmente porque está constantemente monitorando a sua compreensão. Castro e Pereira (2004) também corroboram as palavras de Brown (1980) ao afirmarem que muitos dos problemas de compreensão apresentados pelos estudantes são consequências da ausência ou da inadequação de estratégias de leitura. Ao comparar o processo de leitura de leitores proficientes e não proficientes, mencionam que, enquanto os primeiros são capazes de julgar seu processo de leitura e, em caso de equívocos, encontrar a causa do problema de compreensão, os segundos não conseguem avaliar se estão ou não entendendo e, portanto, não conseguem identificar ou corrigir problemas de compreensão.

Kleiman (2013) também compartilha dessa opinião afirmando que, se o aluno é capaz de decodificar e analisar a informação sintática do texto e, mesmo assim, apresenta dificuldades de compreensão, é provável que esteja fazendo uso inadequado de estratégias de leitura.

Nesse sentido, é imprescindível que, nas aulas de leitura, propiciem-se situações que orientem o uso de estratégias metacognitivas por parte dos alunos, de modo a incorporá-las em seu comportamento leitor. Isso porque as estratégias metacognitivas, como mencionam Pinheiro e Guimarães (2013, p. 160), "não surgem ao acaso, não se desenvolvem espontaneamente e não amadurecem de forma natural", sendo, portanto, fundamental a atuação do professor como mediador no processo de desenvolvimento dessas habilidades.

É preciso destacar que a escolha da melhor estratégia para cada situação está sujeita a vários fatores, entre eles a maturidade do leitor, a natureza do texto, o trecho que está sendo lido e o propósito da leitura (Kato, 2007). Sendo assim, é importante que a escola diversifique as possibilidades de leitura, trabalhando com diferentes estratégias, em diferentes contextos, com o intuito de munir os alunos de um conjunto de recursos que serão acionados, durante a leitura, para suprir diferentes necessidades.

Nesse contexto, a predição leitora é uma importante estratégia metacognitiva a ser desenvolvida em sala de aula, pois abrange várias outras estratégias. Ao encontrar uma dificuldade durante a leitura, o leitor acionará seu conhecimento prévio para levantar hipóteses que possam decifrar a mensagem, confirmando ou rejeitando suas predições através de um processo de monitoramento que o assegure de que o que está lendo tem sentido ou não (GOODMAN, 1976). Por ser foco deste estudo, a discussão acerca da predição leitora será aprofundada na próxima seção. 


\subsubsection{Predição leitora}

A predição leitora caracteriza-se pela antecipação de conteúdos do texto por meio da interação entre os conhecimentos prévios do leitor e as pistas deixadas pelo autor (GOODMAN, 1976; 1991; SMITH, 2003).

Apesar de considerar as relações entre fonemas, sílabas, palavras, parágrafos etc., Smith (2003) observa que a leitura não pode ser entendida como um processo linear, no qual é realizada uma decodificação letra por letra ou palavra por palavra. Trata-se, na verdade, de um processo de predições realizado pelo leitor, que percorre o texto, antecipando conteúdos e retomando informações, guiado por sua experiência e pelos conhecimentos que traz armazenados na memória, com o intuito de construir os sentidos do texto.

Para Smith (2003), a predição desempenha um papel relevante para a compreensão do texto. Compreender, para o autor, significa encontrar as respostas corretas para as perguntas que são elaboradas durante a leitura. Nesse processo, entram em jogo

todos os esquemas, scripts e cenários que temos em nossas cabeças - nosso conhecimento prévio de lugares e situações, de discurso escrito, gêneros e histórias - possibilitam-nos prever quando lemos, e, assim, compreender, experimentar e desfrutar do que lemos. (SMITH, 2003, p. 34)

No entanto, o autor salienta que essa predição não é uma adivinhação inconsequente, nem envolve apostar ao acaso em qualquer coisa. Spinillo e Mahon (2015) comentam que uma predição é apropriada se for plausível com aquilo que foi veiculado no texto, ainda que não venha a se confirmar. O leitor realiza, segundo as autoras, uma predição inapropriada quando não consegue estabelecer relações com as informações veiculadas no texto. Nesse caso, o investimento de conhecimentos pessoais é muito grande, extrapolando o sentido do texto. Uma predição plausível, ao contrário, parte de informações do texto e de conhecimentos prévios do leitor, associados de forma apropriada.

Nesse sentido, Goodman (1976) comenta que, para uma leitura eficiente, é necessária a habilidade de selecionar elementos importantes do texto a fim de produzir predições corretas. Para ele,

a leitura é um processo seletivo que engloba o uso parcial de pistas selecionadas do input da percepção com base nas expectativas do leitor. Essas decisões provisórias são posteriormente confirmadas, rejeitadas ou refinadas durante o processo. A leitura é, portanto, um jogo psicolinguístico que envolve a interação entre pensamento e linguagem. (GOODMAN, 1976, p. 2)

Pereira (2009) também associa a leitura a um jogo de risco automonitorado em que o leitor faz as suas apostas, controlando-as para, assim, chegar ao êxito. Para ela, a leitura configura-se como atividade essencialmente significativa, dirigida a um objetivo, dependendo de conhecimentos anteriores e encaminhada pelas expectativas do leitor. 
Segundo a autora, a importância da estratégia de predição reside no fato de que seu domínio supõe também o domínio de diferentes conhecimentos linguísticos, pois as pistas que sustentarão ou não as hipóteses do leitor estão distribuídas entre os diversos níveis constitutivos da língua: fonológico, morfológico, sintático, semântico, pragmático e textual (PEREIRA, 2002). Castro e Pereira (2004) exemplificam esse aspecto mencionando que o fato de que nos surpreenderíamos se, na seção de moda de um jornal, encontrássemos reportagens policiais, revela a existência de uma ideia prévia sobre o material linguístico em questão, sobre sua estrutura textual.

O uso da estratégia de predição implica, portanto, uma atuação ativa do leitor e um acompanhamento consistente e atento do processo de leitura, já que se supõe que quem formula uma hipótese sobre um texto tentará verificar sua validade. Nesse processo, interagem também outras estratégias. É por isso que a predição é considerada uma estratégia abrangente, pois se realiza em conjunto com outras. Para antecipar conteúdos do texto, o leitor baseia-se em deduções (inferência). Para confirmá-las, deverá ficar em constante automonitoramento, buscando no texto as pistas que sustentarão suas hipóteses. Nesse processo, poderá questionar-se sobre suas conclusões, realizando, assim, uma autoavaliação. Para tanto, é provável que o leitor retorne a um segmento anterior por meio de um scanning e dirija atenção a ele por um tempo significativo, realizando uma leitura detalhada de modo a resolver seu questionamento. Caso encontre alguma pista que contrarie suas predições, deverá alterar sua hipótese, utilizando-se da estratégia de autocorreção (PEREIRA, 2012). É possível dizer, então, que o caráter predititivo da leitura está associado ao processamento descendente, enquanto o processamento ascendente é responsável pela confirmação e revisão das hipóteses levantadas pelo leitor durante a leitura.

Castro e Pereira (2004) destacam que o uso dessa estratégia torna menos trabalhoso o processamento da leitura, pois antecipar aspectos do texto permite que as relações entre as sequências sejam estabelecidas sem demandar muitas retomadas. Quanto mais experiente for e mais conhecimentos tiver o leitor, mais uso fará da estratégia de predição. Em função disso, as autoras comentam que é importante que a escola crie situações propícias para o uso dessa estratégia com certa regularidade. Para a realização de atividades como as sugeridas pelas autoras, pressupõe-se a necessidade da tomada de consciência sobre os elementos linguísticos do texto.

Na seção seguinte, apresentam-se alguns conceitos acerca da consciência linguística e sua relação com a leitura e a compreensão de textos.

\subsection{Consciência linguística}

A consciência tem sido tradicionalmente objeto de estudo da Psicologia em suas diferentes vertentes. Recentemente, no entanto, passou também a ser estudada em pesquisas linguísticas.

Segundo a Psicologia Geral, a consciência "constitui uma qualidade momentânea que caracteriza percepções internas e externas em meio ao 
conjunto de fenômenos psíquicos" (Poersch, 1998, p. 8). Já para a Psicologia Cognitiva, é "o conhecimento que as pessoas têm de seus objetos mentais, sejam eles percepções, imagens ou sentimentos, preocupando-se ela em explicar os processos conscientes, enquanto os envolvidos se encontram em atividades determinadas" (FLORES, 1998, p. 120).

Flores (1998) comenta que é nesse último sentido que a Psicolinguística tem utilizado o conceito de consciência. Nesse caso, a consciência refere-se aos processos conscientes dos indivíduos envolvendo a linguagem ao desempenharem uma tarefa.

Partindo dessa concepção, define-se consciência linguística ou metalinguagem como a capacidade que um indivíduo desenvolve ao tratar a língua como objeto de análise e reflexão, controlando e planejando seus próprios processos linguísticos (Maluf e Gombert, 2008). Essa atividade, como afirmam Spinillo e Simões (p. 538, 2003),

requer do indivíduo um distanciamento em relação aos usos da linguagem e em relação ao seu conteúdo, para aproximar-se de suas propriedades. O indivíduo, em outras palavras, afasta-se do significado veiculado pela linguagem para aproximar-se da forma em que a linguagem se apresenta para transmitir um significado.

Cabe mencionar aqui que o termo metalinguagem pode ser definido de forma diferente segundo a perspectiva adotada, da Linguística ou da Psicolinguística. Na concepção linguística, segundo Gombert (1992), a metalinguagem é considerada o uso da linguagem para referir a ela mesma. Trata-se de um elemento de caráter recursivo, com foco na auto-referenciação. Na concepção psicolinguística, por sua vez, entende-se metalinguagem como a consciência sobre a linguagem e não necessariamente o conhecimento sobre a linguagem. Um exemplo dessa diferença seria o fato de uma criança poder manifestar bom desempenho em questões que envolvem a manipulação de fonemas (perspectiva psicolinguística) sem saber o que o termo fonema significa (perspectiva linguística) (TUNMER, PRATT e HERRIMAN, 1984).

Neste estudo, adota-se a perspectiva psicolinguística na qual a atividade metalinguística, ou consciência linguística, envolve tomar a linguagem como objeto de reflexão, analisando suas propriedades a partir de um monitoramento intencional e deliberado. Trata-se de um termo genérico que envolve diferentes habilidades em que diferentes elementos da linguagem são analisados (BARRERA, 2003, p. 66). Pode-se citar, como exemplo dessas habilidades, entre outros, a consciência sobre aspectos fonológicos da língua, denominada consciência fonológica.

Gombert (1992) estudou a consciência linguística e suas diferentes abordagens a partir da análise de pesquisas realizadas por diferentes autores. Desse estudo, apresentou um modelo de desenvolvimento metalinguístico no qual destaca a existência de dois tipos de comportamentos no tratamento da linguagem.

Segundo o autor, durante a aquisição da linguagem, as crianças manifestam comportamentos linguísticos espontâneos, não controlados conscientemente 
e, por isso, elas não são capazes de explicitar verbalmente os tratamentos linguísticos que utilizam. Estes comportamentos, denominados epilinguísticos por Gombert (1992), estão em ação em toda manifestação linguística e evoluem espontaneamente a partir do desenvolvimento da linguagem (SPINILLO, 2009). Segundo Spinillo (2009), são exemplos de atividades que demonstram comportamentos epilinguísticos corrigir uma palavra imediatamente após pronunciá-la, realizar ajustes tais como escolher uma palavra mais apropriada para substituir outra, entre outros. A autora comenta que este tipo de reflexão sobre a linguagem, que é feito de maneira espontânea e em um nível implícito, servirá de base para reflexões futuras mais controladas e explícitas a respeito dos aspectos da linguagem. Essas reflexões resultam em comportamentos autocontrolados, decorrentes de um processo de consciência. Tais comportamentos são denominados comportamentos metalinguísticos.

O contato com a leitura e a escrita em atividades cotidianas mesmo antes do início da alfabetização desenvolveria algumas aprendizagens implícitas sobre a linguagem escrita (comportamento epilinguístico). A aprendizagem escolar, por sua vez, tem papel fundamental no desenvolvimento metalinguístico do indivíduo (Spinillo, 2009, p. 99), uma vez que o aprendizado da escrita exige um esforço para colocar em prática as habilidades de controle intencional dos tratamentos linguísticos, resultando no desenvolvimento de habilidades metalinguísticas, que abrangem diferentes segmentos da língua, como, por exemplo, aspectos fonológicos, lexicais, morfológicos, etc. (MALUF, ZANELLA e PAGNEZ, 2006).

\subsubsection{Consciência textual: um olhar sobre o texto}

Gombert (1992), ao tratar do desenvolvimento metalinguístico, foi quem, pela primeira vez, utilizou o termo consciência textual, iniciando uma discussão a respeito da capacidade do indivíduo de tomar o texto como objeto de análise. Embora não tenha realizado investigações acerca da consciência textual, Gombert (1992) realizou um levantamento de uma série de pesquisas nas quais o texto é tomado como unidade de análise. A partir dessa discussão, introduziu e definiu consciência textual como uma atividade realizada por um indivíduo que trata o texto como um objeto de análise cujas propriedades podem ser examinadas a partir de um monitoramento deliberado em que o foco recai sobre o texto e não sobre seus usos.

Segundo Gombert (1992), o monitoramento intencional que caracteriza a consciência textual se refere tanto aos aspectos formais do texto como às informações apresentadas no próprio texto. Desse modo, o autor o categoriza em monitoramento da coerência, da coesão e da estrutura.

O monitoramento da coerência refere-se à habilidade de refletir sobre as relações de sentido entre as frases que formam um texto. Envolve, segundo Gombert (1992, p. 123), a capacidade de detectar contradições no nível conceitual. Essas contradições podem referir-se a informações apresentadas no próprio texto ou nele implícitas e recuperadas por meio de inferências (coerência intratextual). Podem também referir-se a contradições entre as informações do texto e as já existentes no conhecimento prévio do leitor (coerência extratextual). 
Ampliando esse conceito, considera-se a contribuição de Charolles (1991) ao mencionar algumas meta-regras necessárias para que um texto seja considerado coerente. Assim, um texto coerente deve respeitar o eixo temático, mantendo-se fiel a ele, mas, ao mesmo tempo desenvolvê-lo, fazê-lo progredir. Além disso, é necessário que o texto não apresente contradições temáticas ou linguísticas e que as afirmações nele presentes tenham vínculo, de verdade ou de verossimilhança, com a realidade.

Outro campo considerado por Gombert no monitoramento do texto diz respeito à coesão, que envolve as relações de ligação entre termos de uma frase e a inter-relação entre as sentenças. A coesão refere-se aos marcadores linguísticos do texto que contribuem para sua unidade, tais como conjunções, pronomes, advérbios, entre outros. É ela que permite distinguir um texto de um simples conjunto de frases. O monitoramento da coesão refere-se, portanto, à tomada de consciência desses marcadores e de como eles contribuem para a construção dos sentidos do texto.

Gombert alerta que, embora na prática seja difícil separar coerência e coesão, uma vez que são elementos que se relacionam na construção do sentido do texto, é preciso considerar que enquanto a primeira envolve variáveis semânticas, a segunda engloba variáveis morfossintáticas. Desse modo, pode-se afirmar que, no monitoramento da coesão e da coerência, entram em jogo aspectos relacionados aos diferentes níveis da língua, de modo que a consciência textual, como afirma Pereira (2013), envolve todos os demais tipos de consciência linguística.

O último aspecto a ser considerado é a estrutura textual. Nesse caso, como destaca Spinillo (2009, p. 85), o texto é tomado como unidade de análise a partir de sua organização geral, distanciando-se do conteúdo veiculado para aproximarse da forma, da configuração linguística do texto. Esse monitoramento, portanto, refere-se à reflexão consciente acerca de aspectos que caracterizam os diferentes gêneros textuais.

Tendo em vista esses aspectos, o presente estudo se baseia na concepção de que a predição leitora e a consciência textual estão fortemente conectadas. Isso porque, para levantar hipóteses acerca dos eventos futuros de uma narrativa, considera-se necessário que o leitor realize um monitoramento do texto com foco nas três categorias mencionadas por Gombert (1992). Assim, predições apropriadas são aquelas em que o leitor relaciona as informações do texto ao seu conhecimento linguístico e de mundo, a fim de evitar a formulação de hipóteses incoerentes (coesão e coerência) e ao seu conhecimento textual, de modo a fazer predições que respeitem a estrutura e as características do gênero textual analisado (estrutura textual).

Os próximos tópicos tratam da pesquisa desenvolvida e dos dados e resultados obtidos.

\section{Metodologia}

Neste tópico, é realizada a apresentação do estudo desenvolvido, descrevendo o objetivo, as questões de pesquisa, os participantes, o instrumento, bem como os procedimentos de coleta e análise dos dados. 
O objetivo do estudo foi examinar a compreensão leitora de estudantes do $6^{\circ}$ ano do Ensino Fundamental no que se refere à realização de predições sobre o conteúdo de uma fábula e o nível de consciência textual no uso dessa estratégia, com apoio nos elementos intratextuais e extratextuais. Tendo em vista esse objetivo, orientaram a pesquisa as seguintes questões: a) Qual o desempenho dos participantes no uso da estratégia de predição leitora durante a leitura de uma fábula?, b) Qual o nível de consciência textual no uso da estratégia de predição leitora evidenciado pelos participantes durante a leitura de uma fábula?e c) Que informações (intratextuais e extratextuais) serviram de base para o estabelecimento das predições?

Participaram da pesquisa 55 estudantes com idades entre 10 e 13 anos, de classe média, frequentando o $6^{\circ}$ ano do Ensino Fundamental de uma escola pública da cidade de Porto Alegre/RS. Destes, 27 eram do sexo feminino e 28 , do sexo masculino. A escolha do $6^{\circ}$ ano como foco de pesquisa resultou do fato de essa série ser um período de transição que marca a passagem do Ensino Fundamental I para o Fundamental II. Essa característica reveste essa faixa escolar de especial importância, uma vez que, nessa etapa, é consolidado o trabalho de compreensão realizado nos anos iniciais e se inicia a preparação dos alunos para o desenvolvimento de processos mais complexos a ser realizado nos anos seguintes.

Considerando o objetivo do estudo de investigar o uso da estratégia de predição leitora e com o intuito de evitar viés nos resultados, cabe ressaltar que foram excluídos das análises os dados dos participantes que mencionaram já conhecer o texto presente no instrumento. Desse modo, foram desconsideradas as respostas de 10 dos 55 participantes que responderam ao questionário.

A coleta de dados foi realizada por meio de uma tarefa de predição leitora e consciência textual que teve como objetivo obter dados sobre o desempenho no uso da estratégia de predição leitora e sobre o nível de consciência textual dos participantes em relação aos elementos considerados no uso dessa estratégia durante a leitura da fábula $A$ raposa e o corvo. A opção por investigar um texto literário apoiou-se em estudos (PRADO e PEREIRA, 2014; VIEIRA, 2014) que destacam as dificuldades dos estudantes na compreensão leitora de textos literários, o que aponta para a necessidade de se realizarem mais pesquisas que investiguem como os alunos compreendem esse tipo de texto. A escolha pelo gênero fábula deu-se pela familiaridade dos alunos, uma vez que a fábula é um gênero de tradição oral que faz parte do cotidiano dos estudantes desde muito cedo, sendo recorrente em materiais didáticos para a faixa etária e escolar analisada. Tal fato auxilia no uso da estratégia de predição, pois, além das pistas linguísticas do texto, os conhecimentos prévios são fundamentais para a realização de predições. Ademais, embora textos literários tenham por característica a criatividade e a inovação, o que pode ampliar consideravelmente as possibilidades de encaminhamento dos acontecimentos, a fábula apresenta uma estrutura mais firme que outros gêneros narrativos, uma vez que gira em torno de personagens que representam características humanas pré-determinadas 
e apresenta temas e situações-problemas que tendem a repetirem-se, tais como: a disputa entre personagens que se opõem; o conflito entre o querer e o poder; entre outros (FERNANDES, 2001). Esses aspectos fazem com que o gênero se torne uma opção viável e adequada para uma pesquisa sobre predição leitora, uma vez que restringe as alternativas de continuação, permitindo, desse modo, uma análise criteriosa acerca do processamento dessa estratégia.

Tendo em vista o objetivo de investigar a realização de predições, o instrumento foi elaborado em formato segmentado. Desse modo, o texto foi apresentado em fichas que continham segmentos da história e perguntas que estimulavam o uso da predição. Considerando o intuito de averiguar não só o uso da estratégia de predição leitora como também a capacidade de verbalizar acerca do processo preditivo realizado pelos participantes no que tange ao monitoramento do texto ao utilizarem essa estratégia, o nível de consciência textual foi avaliado por meio de um método de verbalização denominado protocolo verbal de autorrevelação. Nesse tipo de protocolo, o leitor descreve seu processo de leitura no momento em que está lendo (TOMICHT, 2007). Essa modalidade é considerada a mais apropriada para pesquisas cujo foco é o processo de leitura e não seu produto, pois os dados são acessados durante a leitura, diretamente da memória de trabalho. Desse modo, na tarefa de leitura, para cada pergunta de predição havia uma questão correspondente sobre os aspectos considerados pelo leitor para chegar a cada resposta.

Para a elaboração do instrumento, o texto foi dividido em sete partes. Nessa segmentação de cada parte, foi considerada a possibilidade de que predições pudessem ser realizadas a respeito do conteúdo seguinte do texto. Em função disso, os trechos de cada ficha apresentaram tamanhos variados.

Uma primeira versão da tarefa foi submetida à avaliação de cinco juízes, professores de Língua Portuguesa com vasta experiência em sala de aula, que analisaram a clareza, a adequação da linguagem, o conteúdo e a forma de apresentação do instrumento.

Com base nas respostas dos profissionais, foram feitos pequenos ajustes para tornar os enunciados mais claros aos participantes. Além disso, foi modificada a forma de apresentação das perguntas de predição que, na primeira versão, continham alternativas a serem selecionadas pelos participantes. Na versão definitiva, tais alternativas foram excluídas, acatando a sugestão de uma das avaliadoras que considerou que o formato de perguntas objetivas de escolha simples não permitiria analisar a capacidade de realizar predições e sim de selecionar hipóteses elaboradas pela pesquisadora. Outra avaliadora também comentou a possibilidade de que os participantes escolhessem uma alternativa ao acaso, o que prejudicaria a validade dos dados.

A estrutura da versão definitiva do instrumento, contendo as partes em que o texto foi dividido, bem como as perguntas de predição e de consciência textual, é apresentada no Quadro 1. 
Quadro 1 - Estrutura do instrumento de pesquisa

\begin{tabular}{|c|c|c|}
\hline Partes do texto & Perguntas de predição & Perguntas de consciência textual \\
\hline $\begin{array}{l}\text { A raposa e o corvo } \\
\text { Esopo } \\
\text { Os corvos sempre tiveram fama de serem } \\
\text { péssimos cantores. Ninguém gosta de ouvi- } \\
\text { los. Apesar disso, um deles sempre foi muito } \\
\text { vaidoso e não entendia por que era meno- } \\
\text { sprezado pelos outros animais. } \\
\text { Certo dia, uma raposa faminta estava pas- } \\
\text { sando embaixo de uma árvore, quando viu } \\
\text { lá em cima o corvo empoleirado num galho. } \\
\text { Tinha no bico um grande pedaço de queijo. }\end{array}$ & $\begin{array}{l}\text { O que a raposa vai fazer depois de } \\
\text { avistar o corvo? }\end{array}$ & \multirow{7}{*}{$\begin{array}{l}\text { O que o levou a pensar isso? } \\
\text { Para responder à pergunta, você } \\
\text { observou uma pista (palavra, } \\
\text { expressão etc.) apresentada no } \\
\text { texto ou se baseou em seus con- } \\
\text { hecimentos anteriores, coisas que } \\
\text { você já conhecia antes mesmo de } \\
\text { ler o texto? Explique com suas } \\
\text { palavras. }\end{array}$} \\
\hline $\begin{array}{l}\text { A raposa parou e disse: } \\
\text { - Amigo corvo, sabe que não existe nen- } \\
\text { huma outra ave que cante melhor que você? } \\
\text { Elas não sentem inveja sempre que você } \\
\text { canta? }\end{array}$ & O que vai acontecer a seguir? & \\
\hline $\begin{array}{l}\text { O corvo, acreditando no que ouvira, ficou } \\
\text { feliz com o elogio. Finalmente alguém re- } \\
\text { conhecia seu talento de cantor. } \\
\text { A raposa então lhe pediu: }\end{array}$ & O que a raposa pedirá ao corvo? & \\
\hline $\begin{array}{l}\text { - Será que você poderia deliciar-me com } \\
\text { uma de suas melodias? }\end{array}$ & O que vai acontecer a seguir? & \\
\hline $\begin{array}{l}\text { Orgulhoso e de peito estufado, o corvo se } \\
\text { pôs a cantar para mostrar sua voz. }\end{array}$ & $\begin{array}{l}\text { O que vai acontecer depois que o } \\
\text { corvo começar a cantar? }\end{array}$ & \\
\hline $\begin{array}{l}\text { - Caro corvo, sua vaidade é maior que sua } \\
\text { inteligência! }\end{array}$ & O que a raposa vai dizer ao corvo? & \\
\hline Moral: A vaidade é amiga dos tolos. & $\begin{array}{l}\text { Considerando que as fábulas trans- } \\
\text { mitem um ensinamento, qual será o } \\
\text { ensinamento transmitido pela fábula } \\
\text { A raposa e o corvo? }\end{array}$ & \\
\hline
\end{tabular}

Após a aprovação pelo Comitê de Ética, sob o protocolo de Certificado de Apresentação e Apreciação Ética (CAAE) no 55681216.6.0000.5336, solicitou-se aos pais dos alunos, por meio de um Termo de Consentimento Livre e Esclarecido, 
autorização para que seus filhos participassem da pesquisa. Aos alunos voluntários foi entregue o Termo de Assentimento para leitura e assinatura. Foilhes assegurado, ainda, que a pesquisa não influenciaria na nota escolar, sendo destacado seu caráter confidencial.

Após os trâmites éticos, iniciou-se a coleta de dados propriamente dita. $\mathrm{O}$ instrumento foi aplicado a todos os alunos conjuntamente, durante o turno regular de aulas, em períodos destinados à disciplina de Língua Portuguesa. Para a coleta dos dados, os participantes foram informados de que leriam uma fábula. No entanto, o texto seria apresentado por partes. Eles foram orientados a ler cada trecho com atenção e a responder às perguntas propostas, tentando imaginar o que aconteceria em seguida no desenrolar da narrativa. Foram orientados também a relatar, por escrito, se, para responder à pergunta, observaram alguma pista (palavra, expressão etc.) apresentada no texto ou se se basearam em seus conhecimentos anteriores.

Em seguida, os alunos receberam a primeira ficha da tarefa de predição leitora e consciência textual. As fichas seguintes eram distribuídas à medida que cada participante completava e devolvia a anterior. Uma vez entregue, não era permitido consultá-la ou alterá-la. Neste estudo, a coleta de dados ocorreu por meio de fichas respondidas por escrito pelos participantes e não oralmente como tem sido realizado em pesquisas semelhantes (SPINILLO e ALMEIDA, 2014; SPINILLO e MAHON, 2015), tendo em vista os resultados de um estudo piloto realizado, no qual se solicitou que os participantes não só escrevessem suas respostas como também as explicitassem oralmente para a examinadora a fim de verificar se poderiam fornecer respostas diferentes das escritas. Constatou-se, no entanto, que a maioria não conseguiu complementar o que já havia afirmado por escrito, justificando, assim, a opção metodológica adotada.

Para realizar a análise dos dados coletados, as respostas dos participantes foram quantificadas, conforme critérios descritos a seguir.

Para a análise das perguntas de predição foi adaptada a classificação proposta por Spinillo e Almeida ${ }^{1}$ (2014, p. 123-124):

Categoria I (improvável): o participante apresenta respostas incoerentes, improváveis de ocorrer tendo em vista o que foi veiculado no texto até então. Nessa categoria foram também agrupadas respostas que não resultam de um processo de predição, constituindo uma mera repetição de partes do texto sem responder à pergunta.

Categoria II (plausivel, mas incompleta): o participante apresenta respostas coerentes, geradas a partir de informações do texto e de conhecimentos prévios do leitor. Apesar de apropriadas, as respostas classificadas nesta categoria são consideradas incompletas, pois informações importantes são omitidas.

Categoria III (plausivel e completa): respostas classificadas nesta categoria se assemelham àquelas da categoria II, porém consistem em respostas completas, sem que haja omissões de aspectos relevantes que atendam ao que é solicitado na pergunta.

$\mathrm{Na}$ correção dessas perguntas, foram atribuídos 2 (dois) pontos para as respostas classificadas na categoria III, 1 (um) ponto para as classificadas na 
categoria II e 0 (zero) para a categoria I. Cada participante poderia alcançar o máximo de 14 e o mínimo de 0 pontos.

Nas perguntas de justificativa, a consciência dos participantes foi avaliada de acordo com os níveis de consciência textual, elaborados com base nos estudos de Gombert (1992), Poersch (1998) e Spinillo (2009). Os níveis considerados são:

Nivel I (estado pré-consciente): nível de consciência mais elementar, caracterizado pela pouca capacidade de explicitação das informações utilizadas para realizar as predições. O participante encontra-se nesse nível de consciência quando responde a questão de forma confusa e equivocada.

Nível II (comportamento epilinguístico): nível de consciência intermediário, caracterizado pela capacidade relativa de explicitação das informações utilizadas para realizar as predições. O participante encontra-se nesse nível de consciência quando oferece indícios de como processou a questão, mas com formulações vagas e imprecisas.

Nível III (comportamento metalinguístico): nível de consciência mais avançado, caracterizado pela capacidade de explicitação das informações utilizadas para realizar as predições. O participante encontra-se nesse nível de consciência quando demonstra ser capaz de fazer reflexões sobre o texto e sobre seus procedimentos de análise de forma clara e articulada.

$\mathrm{Na}$ correção dessas respostas, foram atribuídos 2 (dois) pontos para as classificadas no nível III, 1 (um) ponto para as classificadas no nível II e 0 (zero) para o nível I. Cada participante poderia alcançar o máximo de 14 e o mínimo de 0 pontos.

Para analisar o desempenho no uso da predição leitora e o nível de consciência textual, as respostas dos participantes foram agrupadas e examinadas de acordo com as categorias de análise estabelecidas. Para análise dos dados, foram utilizados testes estatísticos não paramétricos, assumindo-se um nível de significância de $5 \%(\mathrm{p} \leq 0,05)$. A escolha por esse tipo de procedimento deu-se em função do resultado obtido por meio do teste de Shapiro-Wilk, que tem como objetivo verificar se uma amostra tem distribuição normal (ROYSTON, 1992). Considerando-se o resultado do teste para a análise da distribuição dos escores de predição leitora $(\mathrm{W}=0,892 ; \mathrm{p}=0,0005)$ e de consciência textual $(\mathrm{W}=0,893$; $\mathrm{p}$ $=0,0006$ ), foi possível recusar a hipótese de normalidade dos dados, justificando, assim, a opção por técnicas não paramétricas, uma vez que essas técnicas não assumem hipóteses sobre a distribuição de probabilidade da população da qual se retiram os dados, ao contrário das técnicas paramétricas que supõem que essa distribuição seja conhecida (ROYSTON, 1992).

Sendo assim, para a comparação dos grupos de respostas (categorias de predição e níveis de consciência) adotou-se o teste de Friedman. Esse teste não paramétrico, utilizado para verificar se existe diferença significativa entre três ou mais grupos ou postos em amostras pareadas. Para tanto, os valores numéricos são transformados em postos e agrupados num só conjunto de dados e a comparação dos grupos é realizada por meio da mediana dos postos (SIEGEL, 1988).

Para a análise da pontuação dos participantes nas duas medidas (predição leitora e consciência textual) adotou-se o teste de Wilcoxon. Esse teste tem como 
objetivo comparar o desempenho de cada sujeito a fim de verificar se existem diferenças significativas entre seus resultados em duas situações (SIEGEL, 1988).

Esses dados estão apresentados e analisados no tópico a seguir.

\section{Resultados}

O desempenho dos participantes foi analisado sob dois pontos de vista. Inicialmente, avaliou-se o uso da estratégia propriamente dita para, em seguida, analisar o nível de consciência textual desse uso.

A Tabela 1 apresenta o número e a porcentagem de categorias de resposta às perguntas de predição.

Tabela 1 - Número e porcentagem de respostas às perguntas de uso da predição leitora por categorias

\begin{tabular}{ll}
\hline Categorias & Número/porcentagem \\
\hline $\mathrm{CI}$ & $23(7 \%)$ \\
\hline $\mathrm{CII}$ & $64(20 \%)$ \\
\hline $\mathrm{CIII}$ & $228(73 \%)$ \\
\hline
\end{tabular}

Nota . CI = predição improvável; $\mathrm{CII}=$ predição plausível, mas incompleta; $\mathrm{CIII}=$ predição plausível e completa. Valor de $n=315$.

$\mathrm{O}$ teste de Friedman detectou diferenças significativas entre as categorias de respostas(CI vs CII: $\mathrm{p}<0,05$; CI $v s$ CIII: $\mathrm{p}<0,01$ e CII $v s$ CIII: $\mathrm{p}<0,01$ ), com uma concentração de respostas na categoria III. Ainda que mais da metade das respostas fornecidas fossem consideradas apropriadas, $27 \%$ das respostas oferecidas pelos participantes apresentavam pouca relação com o que era veiculado no texto (categoria I) ou, embora apropriadas, omitiam informações importantes (categoria II).

Além do uso da estratégia, foi verificado, a partir das respostas fornecidas à pergunta de protocolo verbal, o nível de consciência textual no uso dessa estratégia. A Tabela 2 apresenta o desempenho dos participantes sob esse ponto de vista.

Tabela 2 - Número e porcentagem de resposta às perguntas de consciência textual do uso da estratégia de predição leitora por níveis.

\begin{tabular}{ll}
\hline Níveis & Número e porcentagem \\
\hline NI & $25(8 \%)$ \\
\hline NII & $123(39 \%)$ \\
\hline NIII & $166(53 \%)$ \\
\hline
\end{tabular}

Nota . CI = predição improvável; $\mathrm{CII}=$ predição plausível, mas incompleta; $\mathrm{CIII}=$ predição plausível e completa. Valor de $n=315$. 
Com relação aos dados dispostos na Tabela 2, observa-se uma maior frequência de respostas nos níveis II (comportamento epilinguístico) e III (comportamento metalinguístico), não havendo diferenças significativas entre esses dois percentuais, segundo o teste de Friedman $(p=0,15)$.

De um modo geral, os dados da Tabela 2 mostram que pouco mais da metade das respostas fornecidas explicitavam as bases geradoras das prediçóes, indicando as informações intratextuais ou extratextuais utilizadas nas predições. Um percentual considerável das respostas dos participantes sugere um nível de consciência textual intermediário, uma vez que 39\% das respostas apresentavam formulações vagas e imprecisas acerca dos elementos observados durante a realização das predições.

Além das análises anteriores, os dados das Tabelas 1 e 2 foram comparados entre si a fim de verificar diferenças entre as duas variáveis. A Figura 1 apresenta esses dados.

Figura 1. Respostas dos participantes às perguntas de uso da predição e de consciência textual do uso de acordo com as categorias de análise.

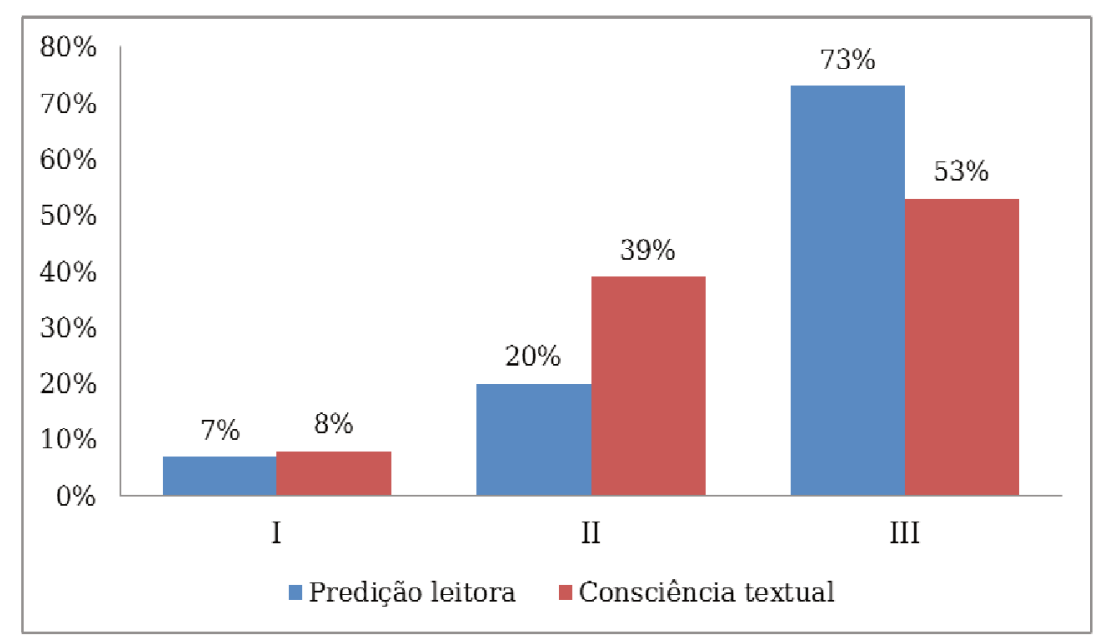

A Tabela 3 apresenta os valores de significância relativos às comparações entre as categorias de uso da predição e os níveis de consciência textual examinados pelo teste de Wilcoxon em relação aos dados da Figura 1.

O teste de Wilcoxon não revelou diferenças significativas entre a categoria I $\mathrm{e}$ o nível I ( $p=0,54)$. Isso significa que o desempenho dos participantes não diferiu nas duas medidas, como pode ser observado pelos percentuais de respostas semelhantes em ambas variáveis ( $7 \%$ e $8 \%$, respectivamente).

As categorias II e III, por sua vez, quando comparadas aos níveis II e III apresentaram diferenças significativas de acordo com o teste estatístico $(p<0,01)$. Analisando-se a Figura 1, percebe-se que, embora a maior parte das respostas às perguntas de consciência textual se concentrem no nível III, o percentual dessas respostas é relativamente inferior ao percentual de respostas na categoria III ( $53 \%$ e 73\%, respectivamente). Isso indica que os participantes investigados apresentam maior dificuldade para explicar como realizaram a predição do que para realizá- 
la, oferecendo, em alguns casos (39\%), indícios de como processaram a questão, mas com formulações vagas ou imprecisas (comportamento epilinguístico).

Além da análise dos dados globais, foi examinado o desempenho dos participantes em cada questão do instrumento, a fim de verificar quais perguntas suscitaram maior dificuldade ou facilidade para o estabelecimento das predições, bem como para a explicitação dos elementos considerados em cada resposta. Os dados obtidos em cada segmento do texto são apresentados na Tabela 6.

Tabela 3 - Número e porcentagem de respostas por categoria em cada uso da predição e por nível de consciência textual em cada pergunta de justificativa

\begin{tabular}{lllllll}
\hline Pergunta & CI & NI & CII & NII & CIII & NIII \\
\hline P1 & $05(11 \%)$ & $04(9 \%)$ & $18(40 \%)$ & $14(31 \%)$ & $22(49 \%)$ & $27(60 \%)$ \\
\hline P2 & $02(4 \%)$ & $03(7 \%)$ & $11(25 \%)$ & $15(33 \%)$ & $32(71 \%)$ & $27(60 \%)$ \\
\hline P3 & $02(4 \%)$ & $01(2 \%)$ & $12(27 \%)$ & $16(36 \%)$ & $31(69 \%)$ & $28(62 \%)$ \\
\hline P4 & $03(7 \%)$ & $03(7 \%)$ & $04(9 \%)$ & $23(51 \%)$ & $38(84 \%)$ & $19(42 \%)$ \\
\hline P5 & $06(13 \%)$ & $04(9 \%)$ & $09(20 \%)$ & $18(40 \%)$ & $30(67 \%)$ & $23(51 \%)$ \\
\hline P6 & $03(7 \%)$ & $06(13 \%)$ & $04(9 \%)$ & $19(42 \%)$ & $38(84 \%)$ & $20(45 \%)$ \\
\hline P7 & $02(4 \%)$ & $04(9 \%)$ & $06(13 \%)$ & $18(40 \%)$ & $37(82 \%)$ & $23(51 \%)$ \\
\hline
\end{tabular}

Nota . $\mathrm{CI}=$ predição improvável; $\mathrm{CII}=$ predição plausível, mas incompleta; $\mathrm{CIII}=$ predição plausível e completa; $\mathrm{NI}$ = estado pré-consciente; $\mathrm{NII}$ = comportamento epilinguístico; $\mathrm{NIII}=$ comportamento metalinguístico. Valor de $n=45$.

A partir dos dados da Tabela 3, observa-se que o item 1 teve o maior percentual de respostas improváveis (11\%). Além disso, também apresentou percentuais mais baixos para respostas plausíveis e completas (49\%). É importante destacar que essa pergunta foi feita logo após a situação inicial, quando o leitor ainda dispõe de poucas informações sobre a trama. Para alguns participantes, essas informações não foram suficientes para antecipar os fatos desencadeadores da situaçãoproblema. Uma possível explicação é que, ao não encontrar no texto informações literalmente expressas sobre os eventos, esses participantes tendem a apoiar suas predições exclusivamente em seu conhecimento prévio, oferecendo respostas que apresentavam pouca relação com o que era veiculado no texto (categoria I) ou que, embora apropriadas, omitiram informações importantes (categoria II), como pode ser visto na resposta de um participante que conseguiu prever que a raposa tentaria prejudicar o corvo, mas não foi capaz de levantar hipóteses acerca de como isso ocorreria: (1) Eu acho que a raposa vai fazer mal ao corvo. ${ }^{2}$

Os participantes que conseguiram fazer predições plausíveis indicaram que a raposa, provavelmente, tentaria enganar o corvo para tomar-lhe o queijo que tinha no bico, como pode ser visto nas respostas: (2) Eu acho que a raposa vai agradar o corvo para que ele dê o pedaço de queijo para ela.(3) A raposa irá inventar uma desculpa e fazer o corvo descer e então roubará o queijo. 
Alguns participantes conseguiram prever que a raposa tentaria prejudicar o corvo, mas, como não observaram as pistas linguísticas que mencionavam o queijo, caminharam para outra direção, imaginando que a raposa queria distrair o corvo para comê-lo.

Com relação à explicitação dos elementos utilizados para a formulação da resposta, a maioria baseou-se em pistas linguísticas presentes no texto: o queijo que estava no bico do corvo e o adjetivo "faminta" para referir-se à raposa, o que justificaria seu interesse no alimento. Alguns participantes não só observaram as informações intratextuais, como também as relacionaram com seus conhecimentos prévios para chegar a uma conclusão: (4) Eu pensei nisso pois geralmente a raposa é esperta e gosta de se aproveitar dos outros e como ela estava faminta, isso me fez pensar que ela queria o queijo do corvo.

Percebe-se, nessa resposta, que o participante foi capaz de acionar seus esquemas (SMITH, 2003) sobre as características comuns aos personagens de uma fábula para elaborar sua predição. Assim, sabendo que, nas fábulas, as raposas tentam obter vantagens ao enganar os demais e que, naquele momento, o corvo estava com um pedaço de queijo, o aluno pôde concluir que ela, provavelmente, pretendia ludibriá-lo para conseguir o alimento para si. Essa resposta demonstra a proficiência desses participantes no emprego da estratégia de predição, pois foram capazes de acionar seus conhecimentos prévios sobre o gênero textual e ancorá-los nas pistas apresentadas pelo texto para embasar suas hipóteses, em uma interação entre pensamento e linguagem (GOODMAN, 1976).

É importante comentar a resposta de um dos participantes, considerada improvável: (5) Eu acho que a raposa vai ofender o corvo para fazer ele descer da árvore e então vão discutir sobre quem é o mais belo deles.

$\mathrm{Na}$ justificativa, o participante comenta: (6) O que me levou a pensar isso foi a expressão dita no primeiro parágrafo que o corvo era um dos animais mais feios da floresta e também me inspirei em uma fábula que já tinha lido que era parecida com essa.

Esse tipo de leitor, como menciona Kato (2007), utiliza mais seu conhecimento prévio do que as informações veiculadas no texto, levando-o a tirar conclusões apressadas que comprometem a compreensão. Pelas respostas fornecidas, percebe-se que o conhecimento de mundo sobre a representação do corvo como um animal feio e o conhecimento acerca de outra fábula, na qual um corvo e um pavão discutem sobre quem é o mais belo, influenciou a tal ponto o processamento da leitura que o leitor não observou que no primeiro parágrafo é mencionado que o corvo é um dos piores cantores da floresta e não um dos mais feios. Isso demonstra, como mencionam Castro e Pereira (2004), que o leitor não pode apenas considerar seu conhecimento prévio sem basear-se nos elementos linguísticos do texto, pois corre o risco de construir um sentido equivocado, que extrapola o texto, como no caso do participante citado.

A segunda e a terceira questões solicitavam que os participantes fizessem predições acerca das reações dos personagens no desenrolar da trama. Na segunda questão, mais de $70 \%$ dos participantes considerou que o corvo 
acreditaria no elogio da raposa. A base para as predições foi o emprego da palavra vaidoso para referir-se ao corvo e o trecho que mencionava que esses animais eram péssimos cantores, como mostra uma das justificativas apresentadas: (7) Como o corvo era vaidoso ele vai se sentir prestigiado por alguém elogiar sua voz pois tinha fama de cantar mal.

Um dos participantes também se baseou no trecho que comenta que os corvos cantam mal para elaborar sua hipótese, contudo não relacionou essa informação ao trecho que mencionava que aquele corvo era vaidoso e não entendia por que era menosprezado. Desse modo, acabou formulando uma hipótese que não se confirmou: (8) Eu acho que o corvo não vai cair nessa história não, pois ele sabe que é um corvo e que os corvos cantam mal.

Isso mostra a importância de não apenas tomar os elementos linguísticos como suporte para as predições, mas de relacioná-los em nível local e global (CASTRO e PEREIRA, 2004).

Com relação à terceira questão, é importante comentar a resposta de um dos participantes, que formulou uma predição improvável. Ao ser questionado sobre o que a raposa pediria ao corvo, o participante respondeu: (9) A raposa vai pedir para o corvo ensinar ela a voar.

A resposta é considerada improvável porque a continuação deveria situar-se em torno do elogio feito pela raposa à voz do corvo, o que não foi observado pelo participante. Nesse caso, a predição é inapropriada porque o participante não foi capaz de estabelecer relações com as informações veiculadas no texto, baseando sua predição mais em conhecimentos pessoais acerca das características dos animais envolvidos na fábula e de prováveis leituras anteriormente realizadas do que no texto propriamente dito.

Uma das perguntas que suscitou um maior percentual de respostas na categoria III foi a pergunta 4, com mais de $80 \%$ de respostas plausíveis e completas. Nessa questão, o participante deveria antecipar a reação do corvo diante do pedido da raposa. A própria formulação da pergunta, nesse caso, auxiliou no estabelecimento das predições, tendo em vista que a resposta deveria girar em torno da aceitação ou não do pedido. Sendo assim, não foi difícil para os participantes preverem que o corvo aceitaria o pedido da raposa e começaria a cantar, como ilustra a resposta a seguir: (10) O corvo vai ficar muito alegre de alguém pedir para ele cantar uma de suas melodias e então vai cantar a música. Eu pensei nisso porque no primeiro trecho diz que o corvo não entendia porque os outros animais o menosprezavam e quando a raposa disse que gostou da música ele vai querer cantar porque é vaidoso.

Os dados da Tabela 6 revelam que a pergunta 5 ocasionou um maior percentual de respostas na categoria I (predições improváveis). Isso pode ser explicado pelo fato de a predição solicitada pela pergunta envolver a antecipação do desenlace da história, que caracteriza o estabelecimento de um novo estado, diferente do inicial, quando, na fábula lida, as verdadeiras intenções da raposa são reveladas. Esse aspecto justificaria a dificuldade demonstrada por alguns participantes. 
É interessante observar, como comentam Spinillo e Mahon (2015), que uma predição é apropriada se for plausível com aquilo que foi veiculado no texto, ainda que não venha a se confirmar. Esse é o caso da resposta de um dos participantes à questão 5 . Ao ser questionado sobre o que aconteceria depois que o corvo começasse a cantar, o participante responde: (11) A raposa não vai gostar da voz do corvo e vai xingar ele. No começo da fábula está escrito que os corvos são péssimos cantores, então eu imaginei que ele iria cantar mal e que a raposa não ia gostar de ouvir ele cantar.

Embora não seja o que acontece na sequência, com base no trecho que menciona que os corvos são péssimos cantores e que ninguém gosta de ouvi-los, o participante prevê que a raposa não gostará do canto do corvo.

Cabe destacar também a resposta de um dos participantes que, na primeira pergunta, havia mencionado que a raposa tentaria comer o corvo. Ao ser perguntado sobre como a história continuaria após o corvo aceitar a proposta da raposa, o participante comenta: (12) Quando ele começar a cantar ele vai derrubar o queijo e a raposa vai pegar o queijo.

E explica: (13) No começo eu achei que a raposa queria comer o corvo mas agora eu percebi que o que ela queria era o queijo, pois quando o corvo abrir o bico para cantar, o queijo que estava no bico vai cair e ela vai conseguir pegar.

Com essa resposta, percebe-se que o participante realizou a predição em interação com as estratégias de automonitoramento, autoavaliação e autocorreção, pois percebeu seu equívoco e corrigiu o rumo de sua leitura, focando sua atenção no queijo, elemento chave da fábula. Tal fato demonstra que a predição leitora é uma estratégia abrangente, pois, para que haja a compreensão do texto, é necessário não só realizar predições apropriadas, como também monitorar seu processo de leitura, de modo a checar e revisar suas hipóteses, como mostrou o processo realizado pelo participante mencionado. Outros participantes que previram, no início da leitura, que a raposa queria comer o corvo, não conseguiram, no entanto, avaliar suas hipóteses e mantiveram o rumo de suas predições anteriores e imaginaram que o corvo, distraído com a cantoria, seria devorado pela raposa. O que diferencia o leitor proficiente do leitor não proficiente, nesse caso, é justamente a capacidade de, frente a um problema de compreensão, avaliar seu percurso de leitura e direcionar sua atenção para o ponto possível gerador da falha de compreensão (CASTRO e PEREIRA, 2004).

Ainda com relação à questão 5, os dados mostraram que, assim como nas questões 1 e 3, o percentual de respostas no nível I (9\%) foi menor que o percentual de predições classificadas na categoria I (13\%). Isso ocorreu porque, como explicado anteriormente, alguns participantes, apesar de realizarem uma predição improvável, foram capazes de justificar seus equívocos, indicando o trecho ou o conhecimento prévio em que se basearam. Um exemplo disso é a hipótese levantada por um dos participantes, que imaginou que, assim que o corvo começasse a cantar, ele e a raposa seriam atacados pelos outros animais da floresta. Embora seja uma predição improvável, pois não considera diferentes elementos mencionados na fábula que conduzem a outro encaminhamento para 
os eventos, o participante justifica seu raciocínio com consistência: (14) Como no texto fala que os corvos cantam mal e que ninguém gosta de ouvi-los eu imaginei que quando ele cantasse todos na floresta iam detestar e iam atacar o corvo e a raposa porque ela fez ele cantar.

Essa justificativa indica certo nível de consciência textual por parte do participante, já que demonstra a necessidade de embasar a resposta, ainda que improvável, em informações textuais.

A questão 6, assim como a 4, foi uma das questões com maior percentual de respostas na categoria III. Essa questão trata da situação final, retomando, na fala da raposa, elementos evidenciados nas questões anteriores, o que provavelmente facilitou a realização das predições, como mostra a resposta de um dos participantes: (15) Acho que a raposa vai dizer que o elogio era mentira e vai ofender o corvo. O que me levou a pensar isso foi o fato de o primeiro trecho dizer que os corvos cantam mal o que mostra que a raposa estava mentindo e também que ela roubou o queijo do corvo mostrando que ela não queria elogiá-lo e sim roubá-lo.

A pergunta 7 também apresentou percentual elevado de respostas na categoria III (82\%). Nela, o participante deveria antecipar a moral da história. Esse resultado pode ser explicado pelo fato de, nessa fábula, a moral recuperar aspectos mencionados na última fala da raposa.

Finalizada a exposição dos dados coletados e dos resultados obtidos, são apresentadas a seguir as conclusões do estudo.

\section{Conclusões}

O presente artigo tem como eixo o uso da estratégia de predição na leitura de fábulas e a consciência desse uso, por alunos do $6^{\circ}$ ano do Ensino Fundamental de uma escola pública de Porto Alegre, sendo esse eixo objeto de pesquisa e de reflexões sobre o ensino na escola. Desse modo, ao longo do texto, são feitas conexões psicolinguísticas entre resultados da investigação realizada e proposições para o ensino.

Para seu desenvolvimento, foram tratados e analisados dados obtidos junto a esse público por meio de um instrumento ad hoc constituído de perguntas preditivas sobre uma fábula e de solicitação de explicações das respostas apresentadas. Desse modo, os dados consistiram nas predições realizadas durante a leitura de uma fábula, respondendo a essas perguntas, e nas explicações dos procedimentos utilizados nessas predições, e as análises evidenciaram o desempenho dos alunos no uso dessa estratégia e na consciência sobre esse uso, retomado neste fechamento.

Os resultados referentes ao uso da estratégia de predição leitora de fábulas se distribuíram progressivamente entre improváveis, plausíveis incompletas e plausíveis completas, com predomínio para este terceiro nível, indicando que a maioria dos alunos manejou bem essa estratégia de leitura, fazendo antecipações pertinentes, embora $27 \%$ deles ainda não tenham tido sucesso nesse empreendimento. 
Com relação à consciência textual no uso dessa estratégia, pouco mais da metade dos alunos evidenciaram comportamento metalinguístico, tendo sido capaz de explicar com eficiência as bases geradoras de suas predições com informações intratextuais ou extratextuais, enquanto $47 \%$ não alcançou esse êxito.

Quanto aos dois tópicos do eixo do artigo, o uso da predição e a consciência desse uso, os resultados mostraram maior dificuldade dos alunos para justificar com eficiência a realização de predições do que para usá-las com pertinência, pois, em alguns casos, ou não conseguiram explicar o processamento da questão (estado pré-consciente) ou fizeram essas explicações com formulações vagas ou imprecisas (comportamento epilinguístico). Revelaram, assim, a existência de um vazio no preparo dos estudantes ainda não bem preenchido pelo trabalho escolar.

Tais resultados não são únicos da pesquisa aqui relatada. Pesquisas realizadas anteriormente também sobre o uso e a consciência no uso de estratégias de leitura de gêneros diversos, com alunos de diferentes escolaridades já revelaram condições próximas. Entre elas, a de Pereira e Vargas (2017) apontou dificuldades de alunos de $9^{\circ}$ ano do Ensino Fundamental, tanto no uso como na consciência do uso, na predição leitora de fábulas, indicando que alunos com maior escolaridade permanecem com dificuldades nesse campo do conhecimento lingüístico. Revelou também que um ensino voltado para esse eixo oferece contribuição importante para superação dessa situação.

Como se vê, os resultados da pesquisa aqui relatada, bem como da mencionada no parágrafo anterior, sugerem que tanto o uso da predição leitora quanto a consciência sobre esse uso são tópicos de trabalho inadiáveis nas aulas de Língua Portuguesa, pois oferecem ao professor informações sobre o processo de leitura dos alunos, em suas possibilidades e dificuldades.

O aluno, ao ser estimulado a dirigir sua atenção para determinado ponto do texto, é levado a refletir sobre o que está lendo. Ao formular uma hipótese para responder a determinada pergunta, faz uso de seu conhecimento prévio, baseando-o em elementos que compõem o texto. Cabe ao professor, ao observar uma escolha equivocada, verificar o ponto em que o aluno teve dificuldade de compreensão e orientá-lo para que direcione sua atenção à relação entre os elementos linguísticos do texto e os conhecimentos prévios, o que o levará à correção de rumos e à compreensão. Para que isso ocorra, é importante que os alunos relatem como realizaram suas predições, o que desenvolverá a consciência sobre o texto e sobre seu processo de leitura.

Assim, a metodologia aqui utilizada pode indicar um caminho para um trabalho pedagógico que estimule a consciência e o desenvolvimento de estratégias de leitura, em especial a predição leitora, de modo a preparar o aluno para as diferentes situações de leitura, de diversos gêneros textuais, que terá de enfrentar como leitor competente.

A presente pesquisa fez sua trilha: coletou, organizou e evidenciou dados esclarecedores sobre uso da predição e consciência do seu uso, relevantes para estudos sobre leitura, alertando para a necessidade de os professores voltarem seu olhar para as estratégias de leitura e para o processo de compreensão. A 
Psicolinguística deu seu apoio teórico-metodológico desfiando suas possibilidades de explicitação da complexidade e relevância da compreensão da leitura. A escola se dispôs a enfrentar a verdade, abrindo suas portas para a entrada das pesquisadoras. Os alunos deram conta seriamente do seu fazer, com apoio dos seus pais, dando condições para obtenção das evidências. As pesquisadoras, por sua vez, caminharam pela trilha referida com um olhar voltado para a teoria/ pesquisa e outro para a prática/ensino, com o norte da Psicolinguística, chegando a este momento final de compartilhamento dos processos desenvolvimentos e dos produtos obtidos.

\section{Agradecimentos}

O presente trabalho foi realizado com apoio da Coordenação de Aperfeiçoamento de Pessoal de Nível Superior - Brasil (CAPES) - Código de Financiamento 001.

\section{Notas}

1. A classificação proposta por Spinillo e Almeida (2014) apresenta quatro categorias de análise. No presente estudo, contudo, foram utilizadas apenas três, pois não houve nenhum participante cuja resposta se adequasse aos parâmetros descritos na categoria I, que foi empregada pelas autoras nas situações em que o participante não respondia à pergunta.

2. As respostas dos alunos foram transcritas literalmente.

\section{Referências}

ANÇÃ, M. H. S. Revisitando a consciência linguística: apropriação do conceito por parte de futuros professores de Português. Calidoscópio. São Leopoldo: Unisinos, v. 13, n. 1., 2015, p. $83-91$.

BARRERA, S. D. Papel facilitador das habilidades metalinguísticas na aprendizagem da linguagem escrita. In: MALUF, M. R. (org). Metalinguagem e aquisição da escrita: contribuições de pesquisa para a prática da alfabetização. São Paulo: Casa do Psicólogo, 2003, p. 65-90.

BROWN, A. L. Metacognitive development and reading. In: SPIRO, R. J.; BRUCE, B. C.; BREWER, W. F. Theoretical issues in reading comprehension. New Jersey: Hillsdal, 1980, p. 453-482.

CASTRO, J. S. e PEREIRA, V. W. Leitor e texto: a preditibilidade faz a interação. Calidoscópio. São Leopoldo: Unisinos, v. 2, n. 1., 2004, p. 55 - 60.

CHAROLLES, M. Introdução aos problemas de coerência dos textos: abordagem teórica e estudo das práticas pedagógicas. In: GALVES, C; ORLANDI, E. P e OTONI, P. (Orgs.) O texto: leitura e escrita. Campinas: Pontes, 1998, p. 39 - 85.

COLL, C. Psicología y curriculum. Una aproximación psicopedagógica de la elaboración del curriculum escolar. Barcelona: Laira, 1987.

COLOMER, T. e CAMPS, A. Ensinar a ler, ensinar a compreender. Porto Alegre: Artmed, 2002.

FERNANDES, M. T. Trabalhando com gêneros do discurso: fábula. São Paulo: FTD, 2001. 
FLORES, O. C. Ação-reflexão linguística e consciência. Letras de Hoje. Porto Alegre: EDIPUCRS, v. 33, n. 4, p. 109-140, 1998.

FOUCAMBERT, J. Modos de ser leitor: aprendizagem e ensino da leitura no Ensino Fundamental. Curitiba: Editora da UFPR, 2008.

FULGÊNCIO, L. e LIBERATO, Y. Como facilitar a leitura. São Paulo: Contexto, 2004.

GIASSON, J. A compreensão na leitura. Lisboa: ASA, 2000.

GOMBERT, J. E. Metalinguistic development. Chicago: The University of Chicago Press, 1992.

GOODMAN, K. S. Reading, a psycholinguist guessing game. In: SINGER, H.; RUDDELL, R. Theoretical models and processes of reading. Newark: International Reading Association, 1976, p. 497 - 508.

GOODMAN, K. S. Unidade na leitura: um modelo psicolinguístico transacional. Letras de Hoje. Porto Alegre: EDIPUCRS, v. 26, n. 4, 1991, p. 9 - 43.

KATO, M. A. O aprendizado da leitura. São Paulo: Martins Fontes, 2007.

KINTSCH, W. Comprehension: a paradigm for cognition. Cambridge: Cambridge University Press, 1998.

KLEIMAN, A. Texto e leitor: aspectos cognitivos da leitura. Campinas: Pontes, 2013.

KOCH, I. V. e ELIAS, V. M. Ler e compreender os sentidos do texto. São Paulo: Contexto, 2011.

LEFFA, V. J. Aspectos da leitura: uma perspectiva psicolinguística. Porto Alegre: SagraLuzzato, 1996.

LORANDI, A.. MENEZES, J. T.; SILVA, I. L; SILVA, L. B.; MARQUES, D. M. Consciência linguística: diferentes olhares. Letrônica. Porto Alegre: EDIPUCRS, v. 5, n. 3, 2012, p. $21-44$.

MALUF, M. R.; ZANELLA, M. S. e PAGNEZ, K. S. M. M. (2006). Habilidades metalinguísticas e linguagem escrita nas pesquisas brasileiras. Boletim de Psicologia. v. 56, n. 124, p. 67 - 92.

MALUF, M. R. E GOMBERT, J. E. Habilidades implícitas e controle cognitivo na aprendizagem da linguagem escrita. In: MALUF, M. R. e GUIMARÃES, S. R. K. (Eds.). Desenvolvimento da linguagem oral e escrita. Curitiba: Editora da UFPR, 2008, p. 123 - 135.

MARCUSCHI, L. A. Produção textual, análise de gêneros e compreensão. São Paulo: Parábola Editorial, 2008.

PEDROSA, R. C. Desenvolvimento da leitura em alunos da $2^{a}, 3^{a}$ e $4^{a}$ séries de Escola Rural. Dissertação de Mestrado. São Paulo: PUCSP, 1984.

PEREIRA, V. W. Arrisque-se... Faça o seu jogo. Letras de Hoje. Porto Alegre: EDIPUCRS, v. 37, n. 128, 2002, p. 47-64.

PEREIRA, V. W. Preditibilidade nas séries iniciais: materiais e procedimentos de leitura. Letras de Hoje. Porto Alegre: EDIPUCRS, v. 39, n. 3, 2003, p. 151-164.

PEREIRA, V. W. Predição leitora: procedimentos e desempenhos em ambiente virtual e em ambiente não virtual. Letras de Hoje. Porto Alegre: EDIPUCRS, v. 44, n. 3, 2009 , p. $22-27$.

PEREIRA, V. W. Predição, compreensão e situação de compreensão. Desenredo. Passo Fundo: Revista do Programa de Pós-Graduação em Letras da UPF, v. 7, n. 1, 2011, p. 91-103. 
PEREIRA, V. W. A predição na teia de estratégias de compreensão leitora. Confluência. Rio de Janeiro: Instituto de Língua Portuguesa. v. 1, 2012, p. 81-91.

PEREIRA, V. W. Compreensão da leitura e consciência textual nos anos iniciais. In: Revista Signo. Santa Cruz do Sul: UNISC, v. 38. Especial, 2013, p. 29-43.

PEREIRA, V. W. e SANTOS, T. V. dos. Consciência linguística no uso de estratégias de leitura na escola em tecnologia virtual e tecnologia não virtual. Belo Horizonte, v. 10 , n. 1,2017 , p. $66-82$.

PINHEIRO, L. R. e GUIMARÃES, S. R. K. O processo de ensino-aprendizagem da leitura e o uso de estratégias metacognitivas na compreensão de textos. In: MOTA, M. P. da e SPINILLO, A. G. (Orgs.). Compreensão de textos. São Paulo: Casa do Psicólogo, 2013, p. 151-170.

POERSCH, J. M. Por um nível metaplícito na construção do sentido textual. Letras de Hoje. Porto Alegre: EDIPUCRS, v. 26, n. 4, 1991, p. 127-143.

POERSCH, J. M. Uma questão terminológica: consciência, metalinguagem, metacognição. Letras de Hoje. v. 33, n. 4, 1998, p.7 - 12.

PRADO, L. L. do e PEREIRA, V. W. Leitura de textos literários e não literários no ensino de Língua Portuguesa, com mediação do computador, nos anos finais do Ensino Fundamental.Lingu@ Nostr@, Canoas, v. 2, n. 1, 2014, p. 4-16.

ROYSTON, P. Approximatong the Shapiro-Wilk W-test for non-normality. Statistics and Computing. v. 2, n. 3, 1992, p. 117-119.

SCLIAR-CABRAL, L. Processamento bottom-up na leitura. Revista de Estudos Linguísticos Veredas: Psicolinguística. Juiz de Fora: UFJF, v. 12, n. 2, 2008, p. 24-33.

SIEGEL, S. Non-parametric statistics for the behavioral sciences. Nova Iorque: McGrawHill, 1988.

SMITH, F. Compreendendo a leitura: uma análise psicolinguística da leitura e do aprender a ler. Porto Alegre: Artes Médicas, 2003.

SOLÉ, I. Estratégias de leitura. Porto Alegre: Artmed, 1998.

SOUSA,L.B.deeHÜBNER,L.C.Desafiosnaavaliaçãodacompreensãoleitora:demanda cognitiva e leiturabilidade textual. Revista NeuropsicologiaLatinoamericana. v. 7, n. 1,2015, p. $34-46$.

SPINILLO, A. G. e SIMÕES, P. U. O desenvolvimento da consciência metatextual em crianças: questões conceituais, metodológicas e resultados de pesquisas. Psicologia: Reflexão e Crítica. v. 16, n. 3, 2003, p. 537 - 548.

SPINILLO, A. G. A consciência metatextual. In: MOTA, M. da (Org.). Desenvolvimento metalinguístico: questões contemporâneas. São Paulo: Casa do Psicólogo, 2009, p. $77-113$.

SPINILLO, A. G. A dimensão social, linguística e cognitiva da compreensão de textos: considerações teóricas e aplicadas. In: MOTA, M. P. da e SPINILLO, A. G. (Orgs.). Compreensão de textos. São Paulo: Casa do Psicólogo, 2013, p. 171-198.

SPINILLO, A. G. e ALMEIDA, D. D. Compreendendo textos narrativo e argumentativo: há diferenças? Arquivos Brasileiros de Psicologia. Rio de Janeiro. v. 66, n. 33, 2014, p. 115-132.

SPINILLO, A. G. e MAHON, E. da R. "O que você acha que vai acontecer agora? Um estudo sobre inferências de predição na compreensão de textos. In: NASCHOLD, A.; PEREIRA, A.; GUARESI, R. e PEREIRA, V. W. (Orgs.). Aprendizado da leitura e da escrita: a ciência em interfaces. Natal: EDUFRN, 2015, p. 163 - 188. 
SPINILLO, A. G.; MOTA, M. M. P. e CORREA, J. Consciência metalinguística e compreensão de leitura: diferentes facetas de uma relação complexa. Educar em revista. V. 38, 2010, p. 157 - 171.

STANKE, R. C. S. F. O papel do conhecimento de mundo na aula de língua estrangeira. Caderno de Letras. Rio de Janeiro: UFRJ, n. 23, 2007, p. 131 - 151.

TOMITCH, L. M. B. Desvelando o processo de compreensão leitora: protocolos verbais na pesquisa em leitura. Revista Signo. Santa Cruz do Sul: UNISC, v. 32. n. 53, 2007, p. $42-53$.

TUNMER, W. PRATT, C. e HERRIMAN, M. Metalinguistic awareness in children: theory, research and implications. Nova York: Springer-Verlag, 1984.

VIEIRA, N. M. C. As dificuldades de aprendizagem na leitura de textos literários no Ensino Médio. 66a Reunião Anual da SBPC, 2014.

Recebido em: 10/03/2019

Aceito em: 04/07/2019 